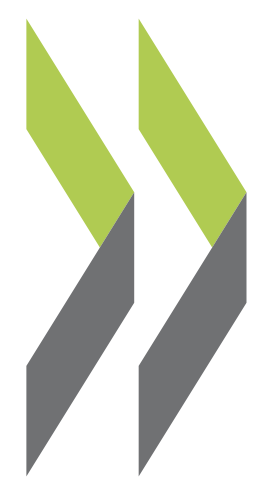

OECD Economics Department Working Papers No. 1314

\title{
Boosting productivity through greater small business dynamism in Canada
}


Organisation de Coopération et de Développement Économiques

Organisation for Economic Co-operation and Development

20-Jul-2016

ECONOMICS DEPARTMENT

English - Or. English

Cancels \& replaces the same document of 06 July 2016

BOOSTING PRODUCTIVITY THROUGH GREATER SMALL BUSINESS DYNAMISM IN CANADA

ECONOMICS DEPARTMENT WORKING PAPERS No. 1314

By David Carey, John Lester and Isabelle Luong

OECD Working Papers should not be reported as representing the official views of the OECD or of its member countries. The opinions expressed and arguments employed are those of the author $(s)$.

Authorised for publication by Robert Ford, Deputy Director, Country Studies Branch, Economics Department.

All Economics Department Working Papers are available at www.oecd.org/eco/workingpapers

JT03399383

Complete document available on OLIS in its original format

This document and any map included herein are without prejudice to the status of or sovereignty over any territory, to the delimitation of international frontiers and boundaries and to the name of any territory, city or area. 
OECD Working Papers should not be reported as representing the official views of the OECD or of its member countries. The opinions expressed and arguments employed are those of the author.

Working Papers describe preliminary results or research in progress by the author(s) and are published to stimulate discussion on a broad range of issues on which the OECD works.

Comments on Working Papers are welcomed, and may be sent to OECD Economics Department, 2 rue André Pascal, 75775 Paris Cedex 16, France, or by e-mail to eco.contact@oecd.org.

All Economics Department Working Papers are available at www.oecd.org/eco/workingpapers.

This document and any map included herein are without prejudice to the status of or sovereignty over any territory, to the delimitation of international frontiers and boundaries and to the name of any territory, city or area.

The statistical data for Israel are supplied by and under the responsibility of the relevant Israeli authorities. The use of such data by the OECD is without prejudice to the status of the Golan Heights, East Jerusalem and Israeli settlements in the West Bank under the terms of international law.

Latvia was not an OECD member at the time of preparation of this paper. Accordingly, Latvia is not included in the list of OECD countries and is not included in the area totals.

\section{(C) OECD (2016)}

You can copy, download or print OECD content for your own use, and you can include excerpts from OECD publications, databases and multimedia products in your own documents, presentations, blogs, websites and teaching materials, provided that suitable acknowledgment of OECD as source and copyright owner is given. All requests for commercial use and translation rights should be submitted to rights@oecd.org 


\section{ABSTRACT/RÉSUMÉ \\ Boosting productivity through greater small business dynamism in Canada}

Small business dynamism is a feature of an SME sector that contributes to overall productivity growth, not an end in itself. Such dynamism increases productivity growth by reallocating resources towards more productive firms and strengthening the diffusion of new technologies. Small business dynamism in Canada has declined in recent decades, as in other OECD countries, but overall it remains in the middle of the range, with some indicators above average and others below. Framework economic policies are generally supportive of small business dynamism, especially labour regulation, but there is scope to reduce regulatory barriers to product market competition. Canada has many programmes to support small businesses. Some of the largest programmes are not well focused on reducing market failures. Focusing support more on reducing clear market failures would increase the contribution of these programmes to productivity growth and living standards. This would likely entail redirecting support from small businesses in general to start-ups and young firms with innovative projects, which would boost small business dynamism.

This Working Paper relates to the 2016 OECD Economic Survey of Canada (www.oecd.org/eco/surveys/economic-survey-canada.htm)

JEL classification codes: D52, H25, L26, O51

Keywords: SMEs, dynamism, start-ups, entry, exit, up-or-out, job churn, productivity, market failures, capital-market failures, venture capital, spill-overs, small-firm taxation, $\mathrm{R} \& \mathrm{D}$ tax credits.

**********

\section{Augmenter la productivité en favorisant le dynamisme des petites entreprises au Canada}

Le dynamisme des petites entreprises n'est pas une fin en soi, mais un élément du secteur des PME qui concourt à la progression globale de la productivité. Il favorise les gains de productivité en redistribuant les ressources vers les entreprises les plus efficientes et en renforçant la diffusion des nouvelles technologies. Au Canada comme dans les autres pays de l'OCDE, le dynamisme des petites entreprises a été moindre ces dernières décennies, mais il reste dans une position médiane, certains indicateurs étant supérieurs à la moyenne de l'OCDE et d'autres inférieurs. Si le cadre de politique économique lui est en général propice, en particulier la réglementation du travail, il existe une marge de réduction des obstacles réglementaires à la concurrence sur les marchés de produits. Alors que de nombreux programmes ont vocation à aider les petites entreprises, certains des plus importants ne ciblent pas bien les défaillances du marché. En les axant davantage sur l'atténuation des dysfonctionnements manifestes, on ferait davantage contribuer ces programmes à la progression de la productivité et du niveau de vie. Il faudrait probablement pour cela réorienter l'aide des petites entreprises en général vers les start-ups et les entreprises de création récente dotées de projets innovants, ce qui donnerait une impulsion à ce segment de l'économie.

Ce Document de travail se rapporte à l'Étude économique de l'OCDE du Canada 2016 (www.oecd.org/fr/eco/etudes/etude-economique-canada.htm)

\section{Classification JEL: D52, H25, L26, O51}

Mots clef: PME, dynamisme, start-ups, entrée, sortie, "croître ou disparaître », renouvellement des emplois, productivité, défaillances des marchés, défaillances des marchés de capitaux, capital-risque, retombées, imposition des petites entreprises, crédits d'impôt pour la recherche-développement. 


\section{TABLE OF CONTENTS}

\section{BOOSTING PRODUCTIVITY THROUGH GREATER SMALL BUSINESS DYNAMISM IN CANADA5}

Small business dynamism has declined, weakening its contribution to productivity growth .....................5

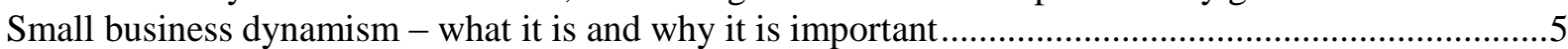

Small business dynamism has declined but remains in the middle of the OECD range ..........................6

The general business environment is favourable for the development of small businesses ....................11

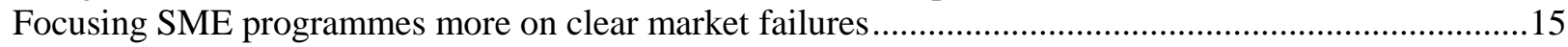

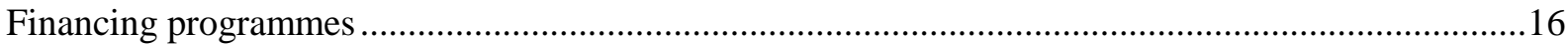

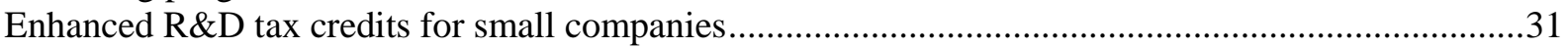

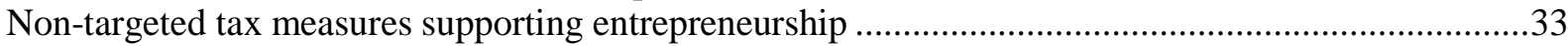

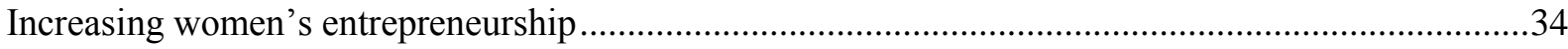

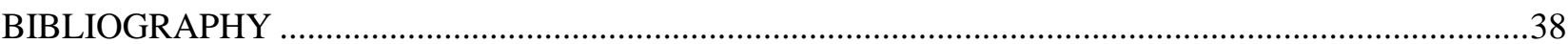

\section{Tables}

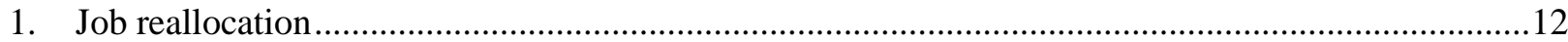

2. Federal tax and spending programmes that support small business and entrepreneurship, 2013 _.....17

3. Rationales for government intervention to support innovative entrepreneurs ..................................18

4. Labour tax rate, employee SSCs and combined statutory rates on dividends under basic and small

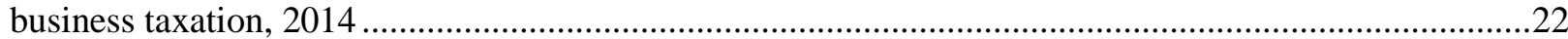

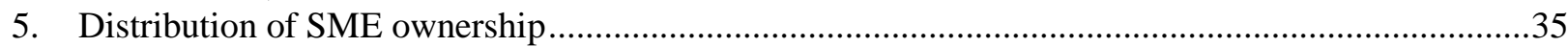

\section{Figures}

1. Small business dynamism has declined but remains in the middle of the range ..................................

2. Net job variation by surviving entrants over total employment......................................................

3. Decomposition of net job creation by surviving entrants relative to total employment ........................8

4. Young SMEs' share of total employment, gross job destruction and gross job creation ........................9

5. Three-year survival and growth outcomes of micro start-ups ..........................................................10

6. Excess job reallocation rates have fallen owing to a fall in job destruction rates .................................10

7. Product market regulation overall is less restrictive than in most other countries...............................13

8. Timeliness of bankruptcy procedures and contract enforcement, 2015 ..........................................14

9. Employment protection legislation in Canada is not restrictive .......................................................14

10. Framework policies and resource flows to patenting firms, 2003-10 ...........................................15

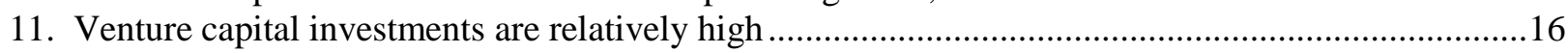

12. Progression of average statutory corporate income tax rates.......................................................21

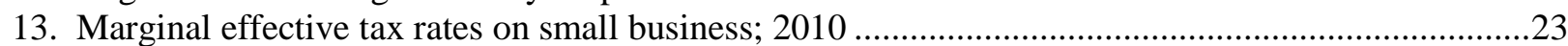

14. The SBD does not alter incentives to grow but encourages tax planning .......................................24

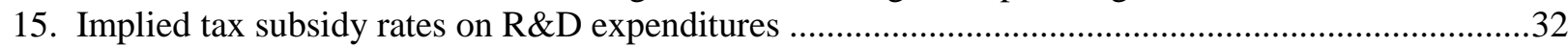

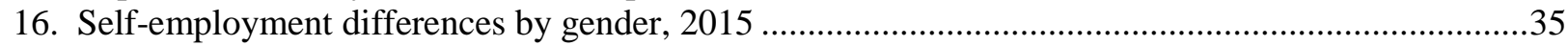

\section{Boxes}

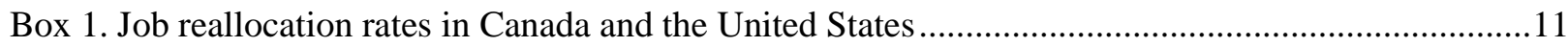

Box 2. Capital market efficiency in the presence of asymmetric information..........................................19

Box 3. Calculating marginal effective tax rates on small-firm investment............................................23 
ECO/WKP(2016)38

\title{
BOOSTING PRODUCTIVITY THROUGH GREATER SMALL BUSINESS DYNAMISM IN CANADA
}

\author{
By David Carey, John Lester and Isabelle Luong ${ }^{1}$
}

Small business dynamism is not an end in itself but rather a feature of an SME sector that contributes significantly to overall productivity growth. Dynamism can be reflected in high rates of firm creation, which also tends to be associated with high exit rates, easy scaling up and a lower share of firms that remain small as they grow old than in a less dynamic sector. This process contributes to productivity growth by introducing new ideas, practices and technologies to the market place and attracting more resources if successful and releasing resources for other uses otherwise.

Indicators of small business dynamism have fallen in Canada, as in many other countries, but mostly remain in the middle of the OECD range. Start-up rates, in particular, have declined to relatively low levels by international comparison. On the other hand, start-ups scale up rapidly over the first few years, although they tend to stagnate subsequently. Job reallocation rates (the sum of job creation and destruction by startups, exiting firms and continuing firms as a share of employment), which are an indicator of resource reallocation, have declined. At the extensive margin (i.e., from firm creation and exit) they are lower than in the United States but higher at the intensive margin (i.e., from continuing firms), pointing to Canada having more pervasive rigidities than the United States in product markets but not in labour markets.

This paper discusses policies for increasing the contribution of the small business sector to productivity growth. It begins by describing what small business dynamism is, why it is important, how it has developed in Canada, and how it compares with that in other countries. A discussion of the general policy framework follows, identifying a few areas where reforms could enhance small business dynamism. The remainder of the paper reviews existing small business programmes and develops recommendations for increasing their contribution to productivity, including by focusing more on overcoming market failures and supporting young, dynamic firms.

\section{Small business dynamism has declined, weakening its contribution to productivity growth}

\section{Small business dynamism - what it is and why it is important}

The dynamism of the small business sector is indicated by rates of firm creation and exit and the extent to which small firms grow into large ones. A dynamic small business sector has many start-ups and young firms that grow rapidly if successful. High start-up rates can reflect intense entrepreneurial activity, which entails experimentation with innovative products, processes and organisational arrangements to test their market value. As many projects prove not to be viable, high start-up rates tend to be associated with

\footnotetext{
1 David Carey and Isabelle Luong are Head of the Canada/New Zealand Desk and Statistician, respectively, in the Economics Department of the OECD, and John Lester is an Executive Fellow at the School of Public Policy at the University of Calgary. Their email addresses are: david.carey@oecd.org John Lester john.lester@sympatico.ca and Isabelle.luong@oecd.org. The authors would like to thank Silvia Appelt (OECD Directorate for Science, Technology and Innovation) Jens Arnold (OECD Economics Department), Robert Ford (OECD Economics Department), Fernando Galindo-Rueda (OECD Directorate for Science, Technology and Innovation), Michelle Harding (OECD Centre for Tax Policy and Administration), Peter Jarrett (OECD Economics Department), Corinne Luu (OECD Economics Department), Marco Marchese (OECD Centre for Entrepreneurship, SMEs and Local Development), Carlo Menon (OECD Directorate for Science, Technology and Innovation), Alvaro Pereira (OECD Economics Department), and Canadian government officials for their valuable comments and suggestions. Special thanks are due to Dacil Kurzweg (OECD Economics Department) and Amelia Godber (OECD Economics Department) for excellent technical preparation.
} 
high exit rates (see below). Such exits release resources for further experimentation and for rapid growth of successful firms (Baldwin and $\mathrm{Gu}, 2006$ ).

A recent OECD study finds that an increase in the share of young firms (i.e., firms younger than six years) relative to older firms (i.e., firms 12 years and older) is associated with higher multifactor productivity (MFP) growth and that this effect is mainly attributable to start-ups (i.e., firms up to two years old) (OECD, 2015a). Moreover, the study finds that an increase in the share of employment in small firms that are no longer young (i.e., firms older than five years with less than 50 employees) relative to larger firms in the same age category (i.e., firms older than five years with 50 or more), which indicates an absence of up-or-out dynamics, is associated with lower MFP growth.

Start-ups, which are more likely to file radical patents than older firms, are often the first link in a chain leading to higher productivity of firms at the global frontier (Andrews et al., 2014; Henderson, 1993; Baumol, 2002). To reach the global productivity frontier, start-ups need to be able to scale up quickly.

\section{Small business dynamism has declined but remains in the middle of the OECD range}

The firm entry rate (the number of entrants as a share of the total number of firms) in the Canadian business sector has been trending down since the early 1980s (Figure 1, Panel A), as has occurred in other countries (Criscuolo et al., 2014). The exit rate has also fallen since the mid-1990s. The trend decline in entry rates has been reflected in falling new entrepreneurship rates (the number of new self-employed workers who hire employees as a fraction of the working-age population). Cao et al. (2015) find that the decline in entry and exit rates does not reflect sectoral shifts in the economy and that population ageing accounts for only a small share (20\%) of the fall in entrepreneurship rates since 2000 (older working-age groups have lower entrepreneurship rates). It is not clear why creating a new firm has become less attractive relative to the alternatives, notably working as an employee. The start-up rate in Canada since the turn of the century appears to be relatively low by international comparison (Panel B). However, these comparisons of small business dynamism indicators and those that follow are subject to considerable uncertainty owing to differences in data collection methodologies. In particular, in contrast to other countries in the sample, data for Canada exclude spurious start-ups and exits resulting from reorganisations or mergers and acquisitions, resulting in Canada having lower rates relative to other countries than it would if measured on the same basis.

The contribution of start-ups to net employment growth appears to be smaller in Canada than in most other countries with data (Figure 2); while these data are for all start-ups, Calvino et al. (2015) demonstrate that similar results are obtained when considering only small-firm start-ups (most start-ups are in fact small). Decomposing this contribution reveals that the low value for Canada mainly reflects a low start-up ratio and small average size at entry (Figure 3). Post-entry growth over the first three years, on the other hand, is the highest among countries with data, pointing to strong dynamics. However, there appears to be little growth in employment on average over the next four years (Calvino et al., 2016). Again, these comparisons are uncertain because Canadian data have been cleaned of reorganisations and mergers and acquisitions. This adjustment tends to reduce Canada's start-up ratio, as noted above, and average firm size at entry but to increase the measured post-entry growth rate.

The relatively low share of smaller (below 50 employees) firms that are younger (less than five years old) (Figure 1, Panel C) points to weaker small business dynamism in Canada than in many other countries, as younger firms tend to be more dynamic than older firms, although again the difference in data methodologies reduces the share of younger firms and increases the share of older firms in Canada compared with other countries. Younger firms in general account for larger shares of job creation and destruction than their share of employment, and their shares of job creation are considerably greater than their share of job destruction; indeed, contrary to popular belief, it is younger firms, especially start-ups, 
that contribute disproportionately to net job creation, not small firms once firm age is controlled for (Haltiwanger et al., 2013). In Canada, younger SMEs (up to 249 employees) account for 38\% of job creation, $21 \%$ of job destruction and only $14 \%$ of employment (Figure 4). These contributions to job creation and destruction are relatively small by international standards, mainly reflecting the relatively low shares of SME employment and of SMEs that are young. From the viewpoint of productivity, the first aspect is an advantage, as large firms are more productive than SMEs (Baldwin et al. (2014) find that in Canada the labour productivity of firms with fewer than 500 employees was only $46 \%$ that of larger firms in 2008), but the second is a drawback, as younger SMEs contribute more to resource reallocation from less to more productive firms than older SMEs.

\section{Figure 1. Small business dynamism has declined but remains in the middle of the range}
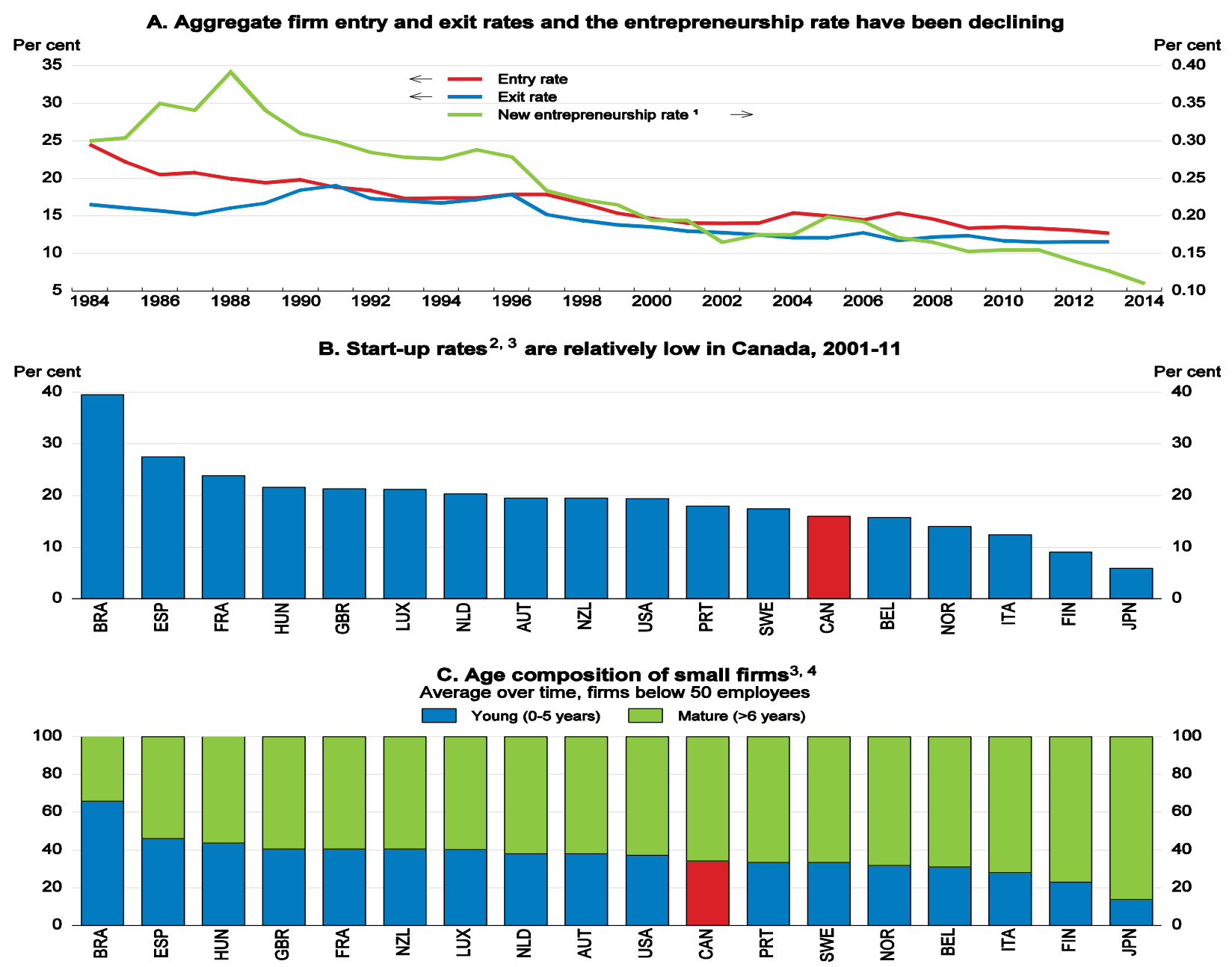

1. The number of new self-employed workers who hire employees as a fraction of the working-age population.

2. Start-ups are defined as those firms which are 0 to 2 years old. Start-up rates are defined as the fraction of start-ups among all firms, averaged across the indicated period. For more details, see Figure 7 in Criscuolo et al. (2014).

3. Data are preliminary. Owing to methodological differences, figures may deviate from officially published national statistics. Data for Canada refer only to organic employment changes and abstract from merger and acquisition activities.

4. Share of firms by different age groups in the total number of micro and small firms (below 50 employees) in each economy on average over 2001-11 (or available years). For more details, see Figure 6 in Criscuolo et al. (2014).

Source: S. Cao et al. (2015), "Trends in Firm Entry and New Entrepreneurship in Canada", Bank of Canada Discussion Paper, No. 2015-11, October, Charts 1 and 3; C. Criscuolo, P.N. Gal and C. Menon (2014), 'The Dynamics of Employment Growth: New Evidence from 18 Countries", OECD Science, Technology and Industry Policy Papers, No. 14, OECD Publishing, http://dx.doi.org/10.1787/5jz417hj6hg6-en. 
Figure 2. Net job variation by surviving entrants over total employment ${ }^{1,2}$

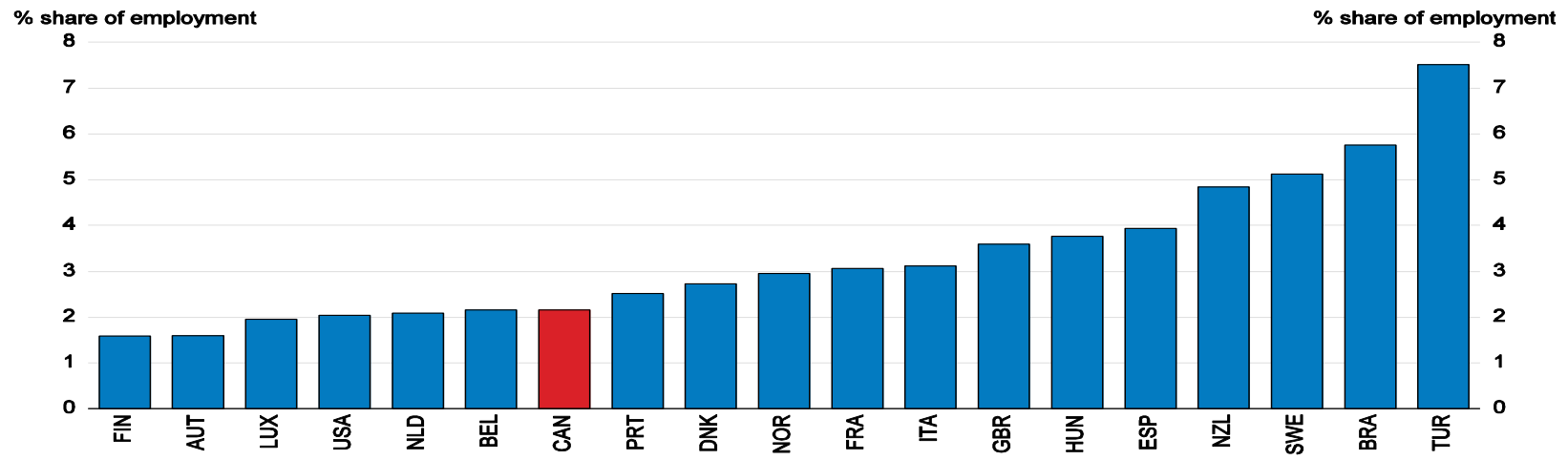

1. The graph illustrates the ratio between employment at time $t+3$ of surviving entrants and overall country employment at time $t$. Figures report the average for different time periods $t=2001,2004$ and 2007, conditional on their availability. Sectors covered are: manufacturing, construction, and non-financial business services.

2. See note 3 in Figure 1.

Source: Calvino, F., C. Criscuolo and C. Menon (2015), "Cross-country Evidence on Start-Up Dynamics", OECD Science, Technology and Industry Working Papers, 2015/06, Paris, Figure 2, http://dx.doi.org/10.1787/5jrxtkb9mxtb-en.

Figure 3. Decomposition of net job creation by surviving entrants relative to total employment ${ }^{1,2}$

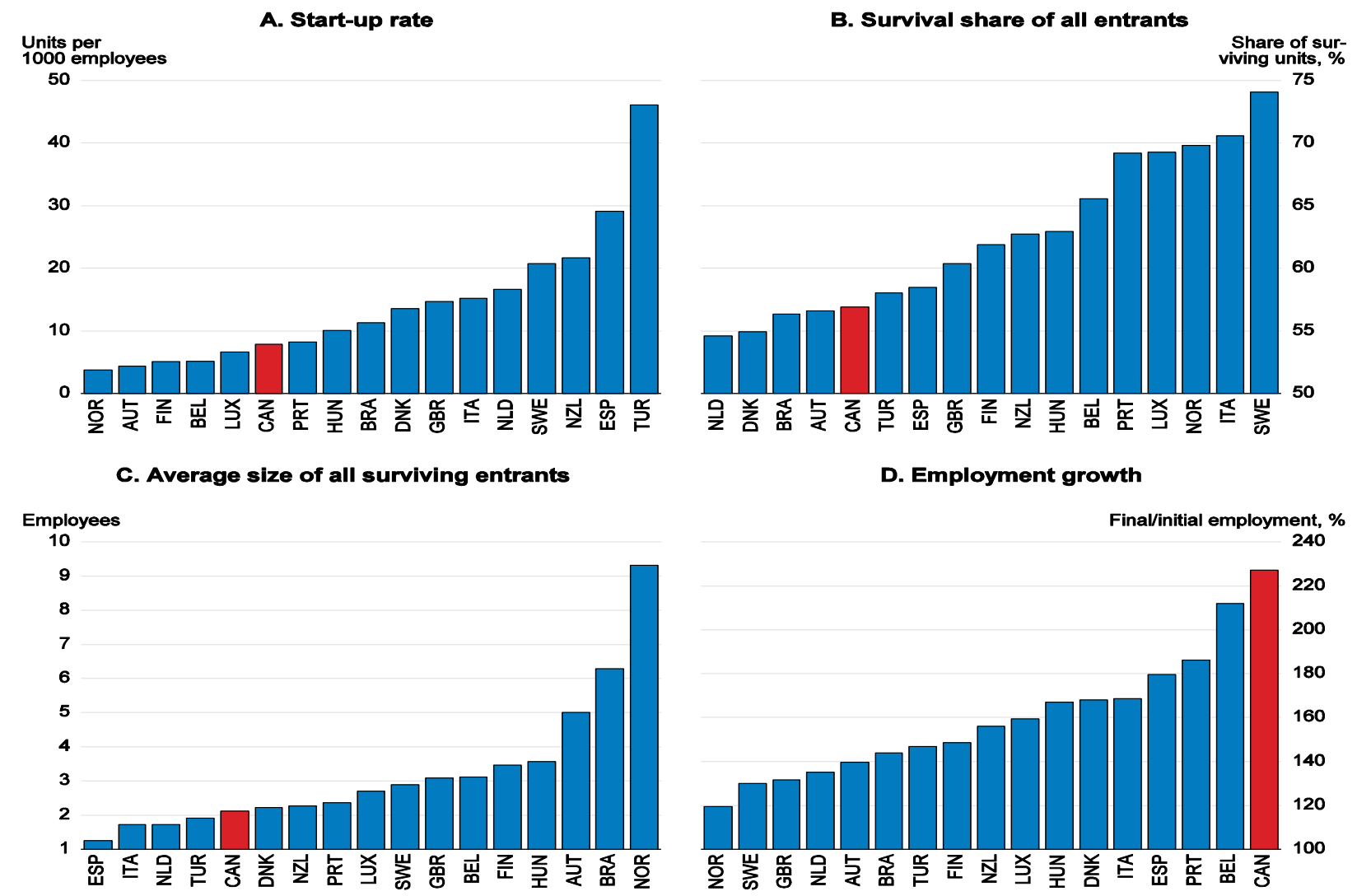

1. For details on these four elements of the growth decomposition and the periods covered, see notes in Figure 1 of Source.

2. See note 3 in Figure 1.

Source: Calvino, F., C. Criscuolo and C. Menon (2016), "No Country for Young Firms?: Start-up Dynamics and National Policies", OECD Science, Technology and Industry Policy Papers, No. 29, OECD Publishing, Paris, http://dx.doi.org/10.1787/5jm22p40c8mwen. 
Figure 4. Young SMEs' share of total employment, gross job destruction and gross job creation ${ }^{1,2}$ Age 0-5 years, up to 249 employees, average 2001-11

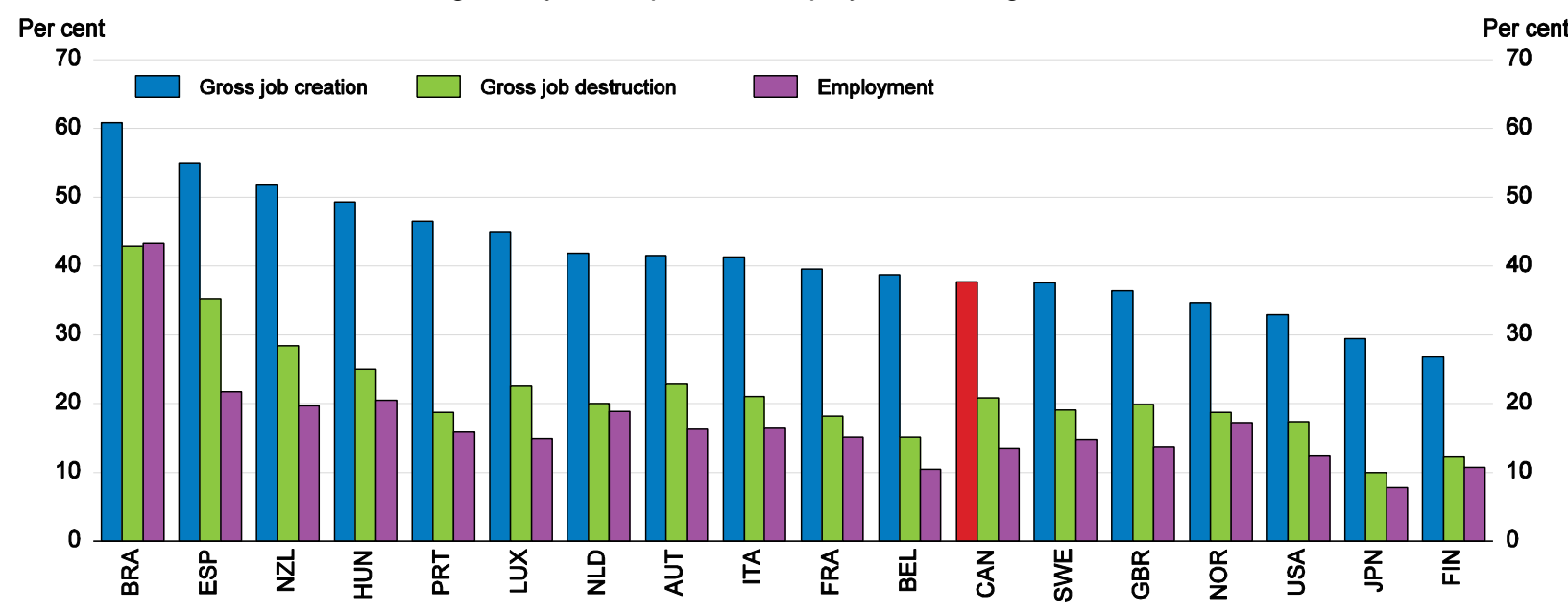

1. For details, see notes in Figure 17 of Source.

2. See note 3 in Figure 1.

Source: C. Criscuolo, P.N. Gal and C. Menon (2014), "The Dynamics of Employment Growth: New Evidence from 18 Countries", OECD Science, Technology and Industry Policy Papers, No. 14, OECD Publishing, http://dx.doi.org/10.1787/5jz417hj6hg6-en.

As in other countries, few microenterprise start-ups in Canada grow beyond microenterprise status (defined in Criscuolo et al. (2014) as 1-9 employees), but those that do account for a disproportionate share of employment growth (Figure 5). Based on longitudinal data following three cohorts (2001, 2004 and 2007) of microenterprise start-ups, Criscuolo et al. (2014) find that the share that grew beyond that status after three years in Canada was $5 \%$ on average, the median value for the countries included in the database. This group accounted for $42 \%$ of microenterprise start-up net job creation, a higher-than-median share $(38 \%)$.

Sectoral excess job reallocation rates (total job reallocation as share of employment in excess of employment growth in the sector concerned), which mainly reflect developments in small firms, are an indicator of the intensity of resource allocation and hence of small business dynamism. Canada's job reallocation rate (the sum of new employment created in all firms that had increasing employment plus the sum of employment destroyed in all firms that had decreasing employment) fell from $24 \%$ in 1992 to $20 \%$ in 2006 (i.e., one in five jobs in the economy was either created or destroyed in the year) (Figure 6, Panel A). As total employment growth rose from - $3 \frac{1}{2}$ per cent in 1992 to $2 \frac{1}{2} 2$ per cent in 2006, the excess job allocation rate fell from around $27 \frac{1}{2}$ per cent in 1992 to around $17 \frac{1}{1 / 2}$ per cent in 2006. Based on the estimated coefficients for excess job reallocation in Cao and Leung (2010), this decline is estimated to have reduced annual rates of multifactor and labour productivity growth by $0.7 \%$ and $1.6 \%$, respectively. It cannot be explained by a rise in the share of workers in large firms but rather mainly reflects a fall in job destruction rates (Panel B).

Controlling for firm size and temporary external factors, job reallocation rates associated with firm births and deaths are significantly lower in Canada than the United States but are higher for continuing firms (Box 1). These results suggest that Canada is less good at facilitating creative destruction through firm entry and exit than the United States, but that it reallocates labour amongst continuing firms efficiently. These results point to Canada having more pervasive rigidities than the United States in product markets but not in labour markets, as suggested by Balakrishnan (2008). 
Figure 5. Three-year survival and growth outcomes of micro start-ups ${ }^{1,2}$

\section{A. Share of firms}

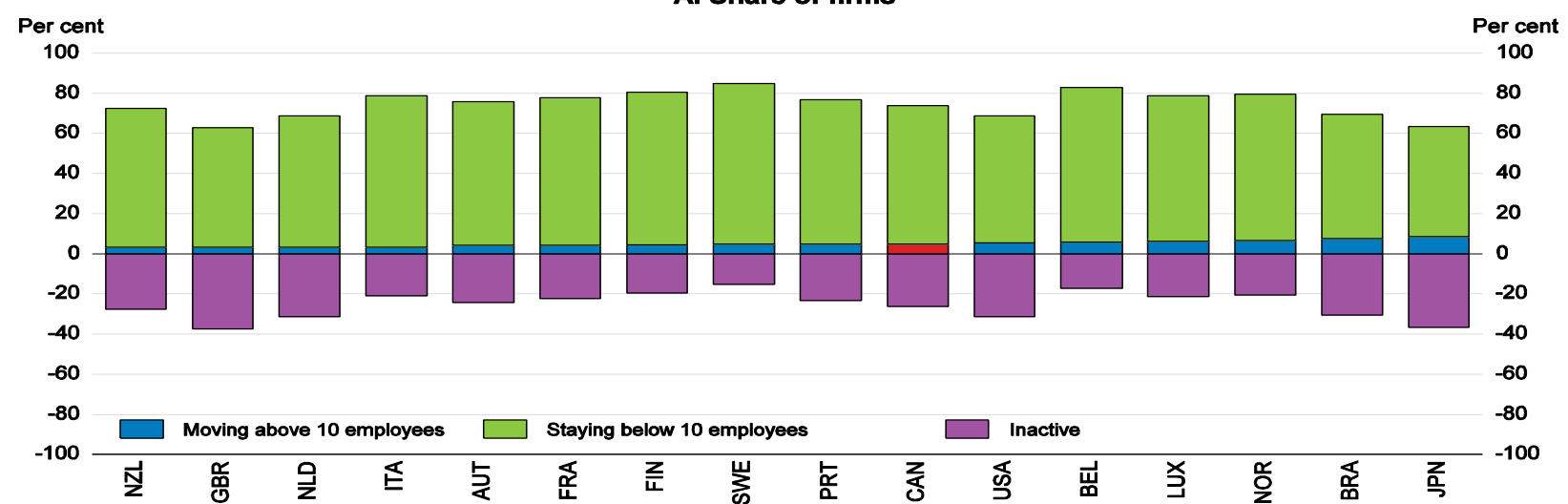

\section{B. Share of jobs affected}

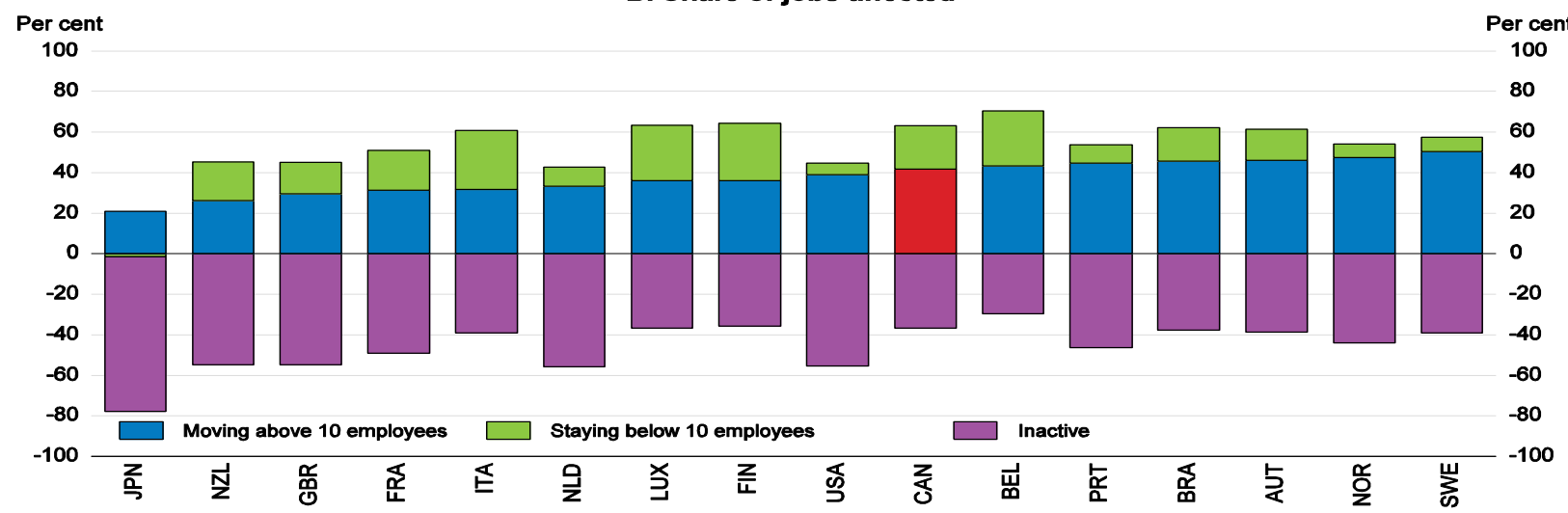

1. Refers to the group of firms that have between zero and nine employees in the beginning of each period and which are $0-2$ years old. Inactive firms do not report information on employment at the end of the three-year period, either because they are temporarily inactive or because they have permanently exited. Sectors covered are: manufacturing, construction non-financial business services. Average of the three-year periods (2001-04; 2004-07; and 2007-10). For more details, see Source.

2. See note 3 in Figure 1.

Source: C. Criscuolo, P.N. Gal and C. Menon (2014), "The Dynamics of Employment Growth: New Evidence from 18 Countries", OECD Science, Technology and Industry Policy Papers, No. 14, OECD Publishing, http://dx.doi.org/10.1787/5jz417hj6hg6-en.

Figure 6. Excess job reallocation rates have fallen owing to a fall in job destruction rates ${ }^{1}$
A. Job reallocation and employment growth rates
B. Job creation and job destruction rates

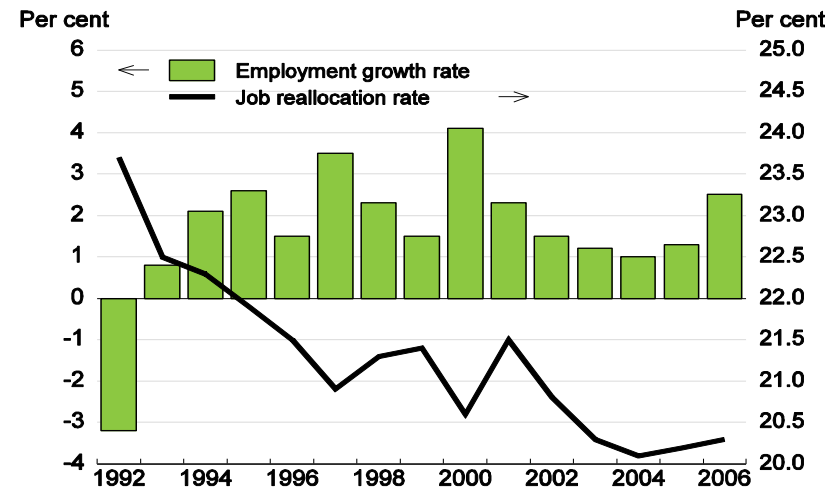

1. Data computed using the Longitudinal Employment Analysis Program (LEAP) database constructed by Statistics Canada.

Source: S. Cao and D. Leung (2010), "Labour Reallocation, Relative Prices and Productivity", Bank of Canada Working Paper, No. 2010-2, January, Figures 6 \& 7. 


\section{Box 1. Job reallocation rates in Canada and the United States}

To isolate country- from firm-size composition effects, we re-run the (OLS) panel regressions performed by Balakrishnan (2008) that take the following form using 2001-13 data instead of 1993-2004 data:

$$
\operatorname{sum}_{i, s, t}=\beta_{0}+\beta_{\text {can }} * D C A N+\sum_{s=1}^{3} \beta_{s} \text { Size }_{s}+\Sigma_{t=01}^{13} \beta_{i} \text { Time }_{t}+\varepsilon_{i, s, t}
$$

where $\operatorname{sum}_{i, s, t}$ is job reallocation in country $i$, firm size category $s$ and time $t$. DCAN is a country dummy variable (DCAN = 1 for Canada, i.e., the benchmark country is the United States), Size $e_{s}$ represents a set of three size dummies (where the categories are firms with 1-19, 20-99 and 100-499 employees and the benchmark is firms with more than 500 employees), and Time $_{t}$ is a set of 12 time dummies (the excluded year is 2001) and $\varepsilon_{i, s, t}$ is the residual.

The results confirm that firm size is a very important determinant of job reallocation rates. Job reallocation rates decline as firm size increases in both countries, except for the job reallocation rate associated with firm births and deaths for firms with 100-499 employees, for which the rate is not significantly different from that for large firms (500 or more employees) (Table 1). These findings concord with the results of other studies that have also found firm size to be a very important determinant of job reallocation rates (e.g., Cao and Leung, 2010; and Haltiwanger et al., 2006). The total job reallocation rate is lower in Canada than in the United States (the Canada dummy is negative and highly significant); this result differs slightly from Balakrishnan's, who also found a lower rate in Canada, but one that was only weakly significant. This reflects a lower job reallocation rate associated with firm births and deaths, confirming Balakrishnan's findings. Again, in line with his results, the job reallocation rate associated with continuing firms is higher in Canada than in the United States.

\section{The general business environment is favourable for the development of small businesses}

A variety of framework policies impinge on the extent to which resources are allocated efficiently, many of which affect small business dynamism. Using a sample of private non-farm sectors, Andrews and Cingano (2014) find evidence that more stringent product market regulations (including barriers to entry and bankruptcy legislation) and labour market regulations adversely affect static allocative efficiency (i.e., the extent to which, all else equal, it is the more productive firms in a sector that command a larger share of aggregate employment). In particular, higher barriers to firm entry and creditor-friendly bankruptcy legislation tend to disproportionately lower allocative efficiency in industries characterised by high firm turnover relative to low-turnover industries. Similarly, tighter labour market regulations disproportionately lower the efficiency of employment allocation in high-layoff and high-turnover industries. Moreover, stringent product market and labour market regulations are more harmful to allocative efficiency in more innovative sectors, which are likely to be subject to greater technological change and thus to place a higher option value on flexibility.

Product market regulation indicators (PMRs) are somewhat less restrictive in Canada than the OECD average (Figure 7). This reflects relatively strong performance in the 'State Control' and 'Barriers to Entrepreneurship' categories of the OECD's PMR indicator, partially offset by relatively poor performance in 'Barriers to Trade and Investment'. The relatively poor performance in barriers to trade and investment reflects high barriers to foreign direct investment (FDI), which Andrews and Cingano (2014) separately found to inhibit allocative efficiency, and differential treatment of foreign suppliers in public procurement. While Canada's relatively low barriers to entrepreneurship overall augur well for business start-ups, there is room for improvement by reducing regulatory protection of incumbents, which is high by international standards. Such protection arises primarily from Canada's above-average use of anti-trust exemptions.

Timely bankruptcy procedures and strong contract enforcement are key to establishing a dynamic start-up environment (Calvino et al., 2016). In Canada, resolving insolvency only takes 0.8 years, one of the shortest times among OECD countries (Figure 8). By contrast, enforcing a contract takes 570 days on average, which is relatively long by international comparison. 
Table 1. Job reallocation

Panel regressions across Canada and the United States, ${ }^{1} 2001-13$

\begin{tabular}{|c|c|c|c|c|c|c|c|}
\hline \multirow{2}{*}{$\begin{array}{l}\text { Dependent } \\
\text { variable }\end{array}$} & & \multicolumn{2}{|c|}{ Total job reallocation rate } & \multicolumn{2}{|c|}{$\begin{array}{c}\text { Job reallocation rate } \\
\text { associated with births } \\
\text { and deaths }\end{array}$} & \multicolumn{2}{|c|}{$\begin{array}{c}\text { Job reallocation rate } \\
\text { associated with } \\
\text { continuers }\end{array}$} \\
\hline & & Coefficient & P-value & Coefficient & $\mathrm{P}$-value & Coefficient & P-value \\
\hline Country & Canada & -3.14 & 0.00 & -3.35 & 0.00 & 0.90 & 0.00 \\
\hline Size & $0-19$ & 28.82 & 0.00 & 17.85 & 0.00 & 14.36 & 0.00 \\
\hline Size & $20-99$ & 11.39 & 0.00 & 2.53 & 0.01 & 8.47 & 0.00 \\
\hline Size & $100-499$ & 6.77 & 0.00 & 0.73 & 0.46 & 5.73 & 0.00 \\
\hline Time & 2002 & -1.98 & 0.12 & -0.36 & 0.84 & -1.59 & 0.02 \\
\hline Time & 2003 & -1.76 & 0.16 & -0.64 & 0.72 & -1.09 & 0.10 \\
\hline Time & 2004 & -3.51 & 0.01 & -1.11 & 0.54 & -2.30 & 0.00 \\
\hline Time & 2005 & -3.22 & 0.01 & -1.21 & 0.50 & -1.93 & 0.00 \\
\hline Time & 2006 & -2.95 & 0.02 & -1.01 & 0.57 & -1.93 & 0.00 \\
\hline Time & 2007 & -3.07 & 0.02 & -1.35 & 0.45 & -1.72 & 0.01 \\
\hline Time & 2008 & -4.11 & 0.00 & -1.47 & 0.42 & -2.64 & 0.00 \\
\hline Time & 2009 & -6.59 & 0.00 & -2.06 & 0.25 & -4.47 & 0.00 \\
\hline Time & 2010 & -6.95 & 0.00 & -2.11 & 0.24 & -4.73 & 0.00 \\
\hline Time & 2011 & -6.07 & 0.00 & -2.06 & 0.25 & -3.90 & 0.00 \\
\hline Time & 2012 & -6.74 & 0.00 & -2.20 & 0.22 & -4.47 & 0.00 \\
\hline Time & 2013 & -6.87 & 0.00 & -2.27 & 0.21 & -4.57 & 0.00 \\
\hline Constant & & 18.73 & 0.00 & 3.65 & 0.01 & 13.66 & 0.00 \\
\hline No. of Obs. & & 104 & & 104 & & 104 & \\
\hline R-squared & & 0.96 & & 0.84 & & 0.95 & \\
\hline
\end{tabular}

1. Database comprises 13 years, 4 size categories and 2 countries. Benchmark for size class is above 500 employees. Benchmark country is the United States. Benchmark for time is 2001.

Source: Statistics Canada, Longitudinal Employment Analysis Program, Table 527-0004; US Bureau of Labor Statistics, Business Employment Dynamics database.

Tighter labour market regulations reduce allocative efficiency within sectors by increasing dismissal costs and thus the costs of workforce adjustments. When such costs are high, firms are less likely to hire workers, even if their marginal product exceeds the market wage, and are more likely to retain workers whose wage exceeds their productivity. Canada has unrestrictive employment protection legislation (EPL), facilitating labour reallocation to more productive uses, especially in high-layoff and high-turnover sectors (Figure 9).

Framework policy settings in Canada, many of which are especially important for dynamic small firms, support dynamic allocative efficiency, which entails resources flowing from less productive to more productive firms over time (Haltiwanger, 2012). A recent OECD study (Andrews et al., 2014) assesses dynamic efficiency in a number of OECD countries by measuring the extent to which resources flow to more innovative firms, where patenting is used as a proxy for innovation. They find that firms that patent more do attract more capital and labour than others and that there are quite large differences in the elasticities of resource flows by country. A number of structural (mostly policy) variables influence the degree to which more innovative firms attract resources (Figure 10). Based on the estimated coefficients for these policies, the authors estimate the extent to which such flows could be increased by moving from the least favourable to the most favourable setting found in the country sample. For example, reducing the stringency of EPL from the highest value (in Portugal) to the lowest value (in the United States) would increase by almost seven times the amount of additional labour attracted to a firm that increases its patent stock by $10 \%$. Canada has policy settings at least as good as the average of the countries included in the study in all areas - access to early-stage venture capital was below average in 2005, the year included in the study, but was third highest in the OECD in 2014, albeit far below the leading countries (Figure 11). 
Figure 7. Product market regulation overall is less restrictive than in most other countries Index scale from 0 (least restrictive) to 6 (most restrictive), 2013

\section{A. Economy-wide regulation}

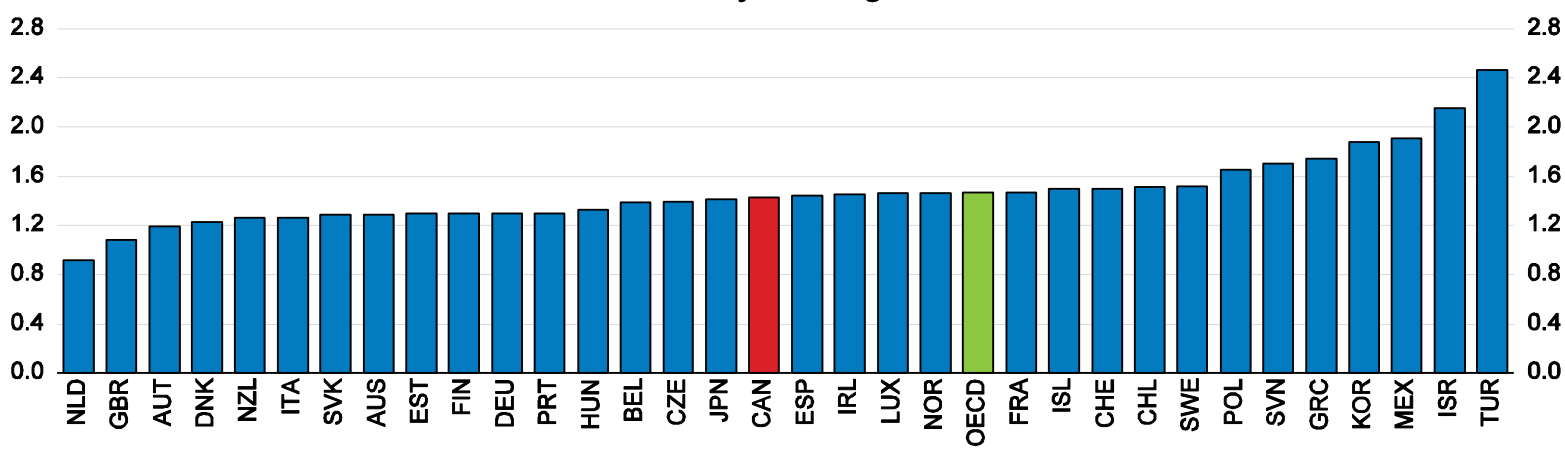

\section{B. State control}

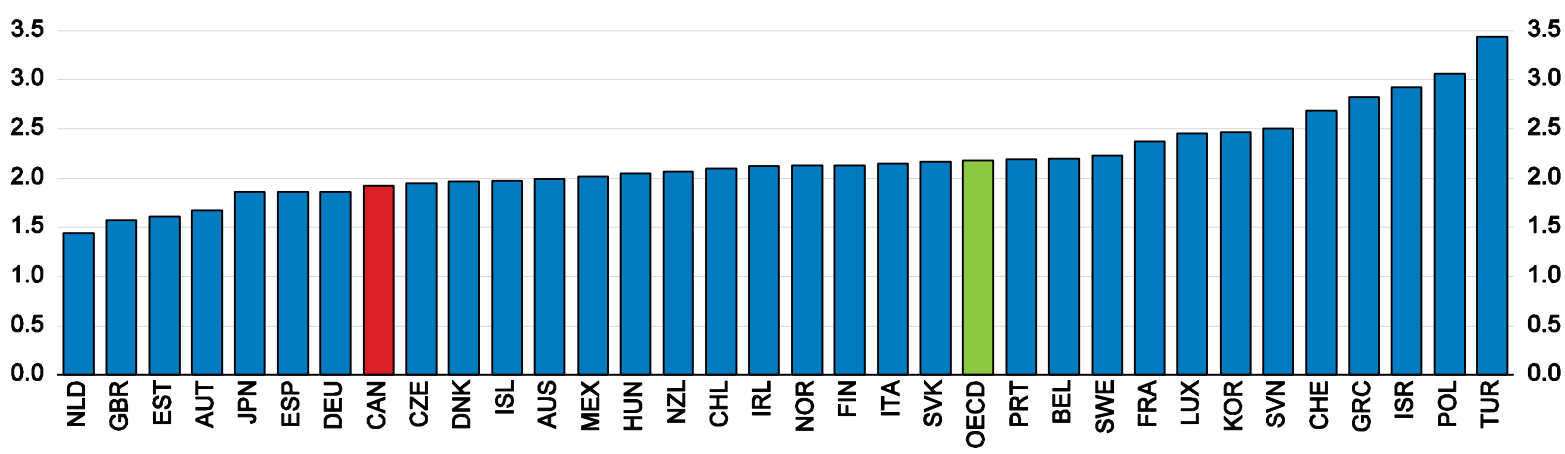

\section{Barriers to entrepreneurship}

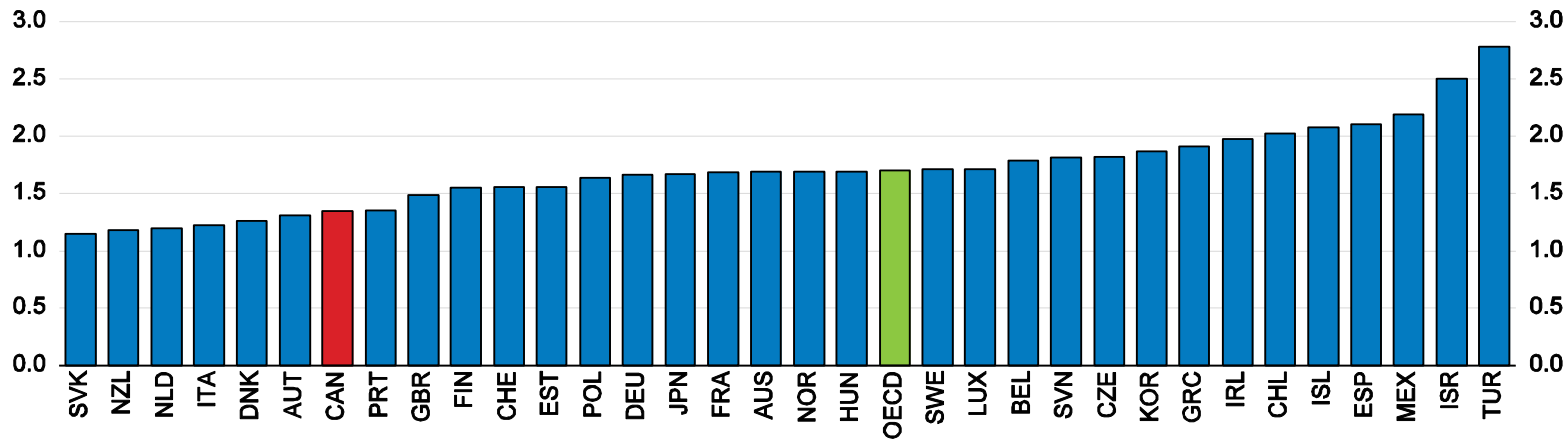

\section{Barriers to trade and investment}

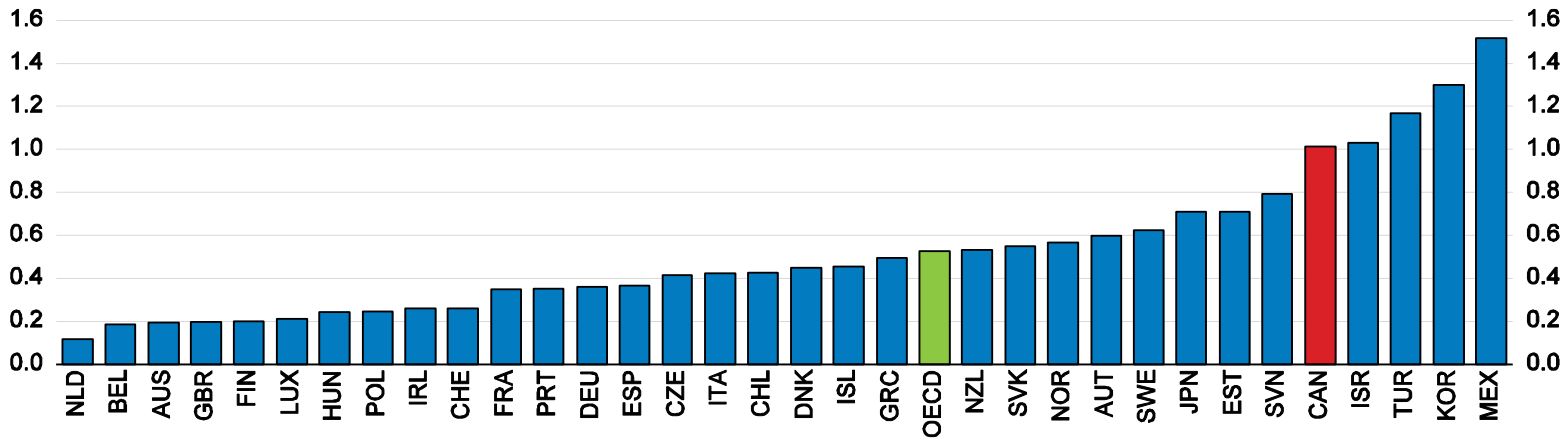

Source: OECD, Product Market Regulation database. 
Figure 8. Timeliness of bankruptcy procedures and contract enforcement, 2015

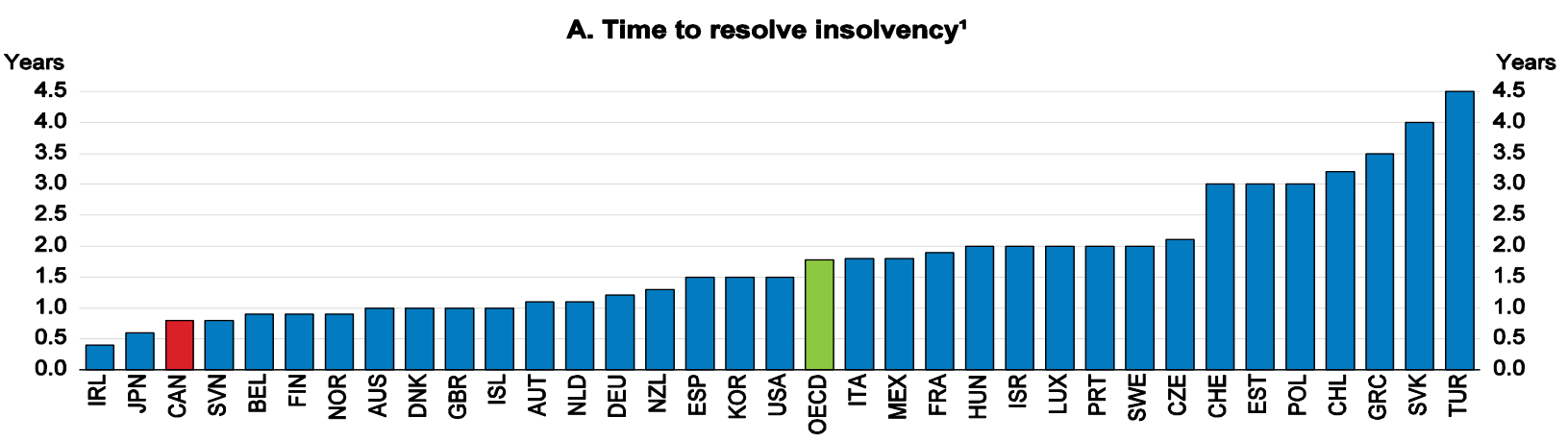

B. Time to enforce a contract

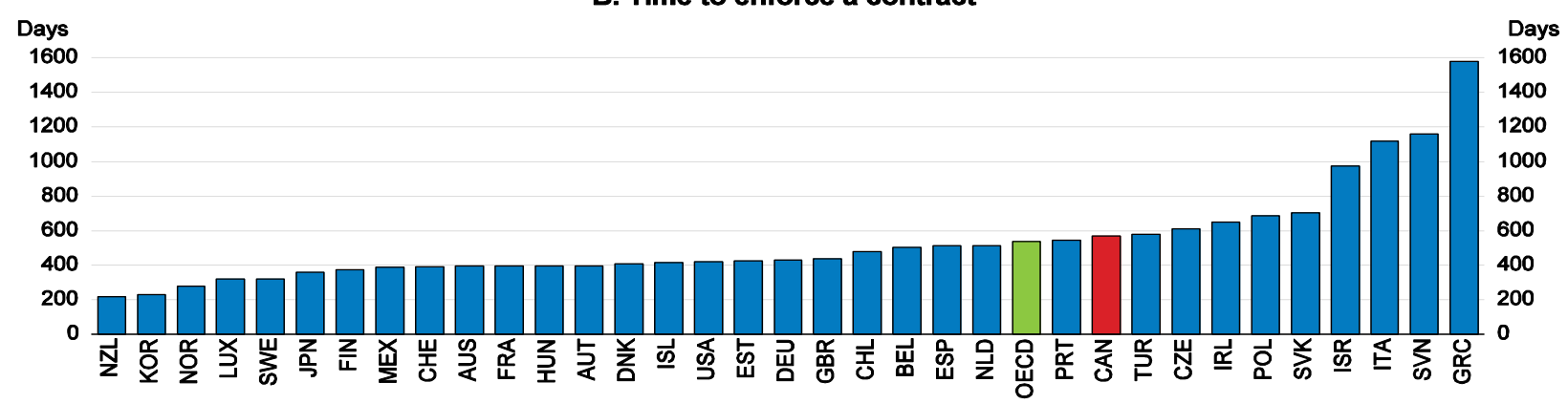

1. Time to resolve insolvency is the number of years from the filing for insolvency in court until the resolution of distressed assets. Source: World Bank, Doing Business database.

Figure 9. Employment protection legislation in Canada is not restrictive Index scale from 0 (least restrictive) to 6 (most restrictive), 2013

A. Protection for regular employment

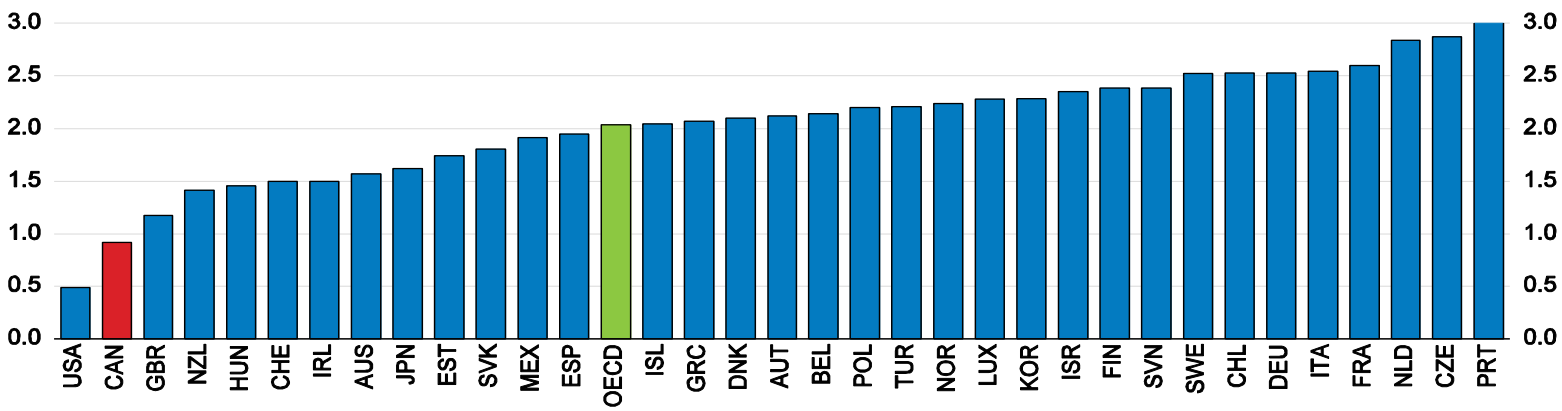

B. Protection for temporary employment

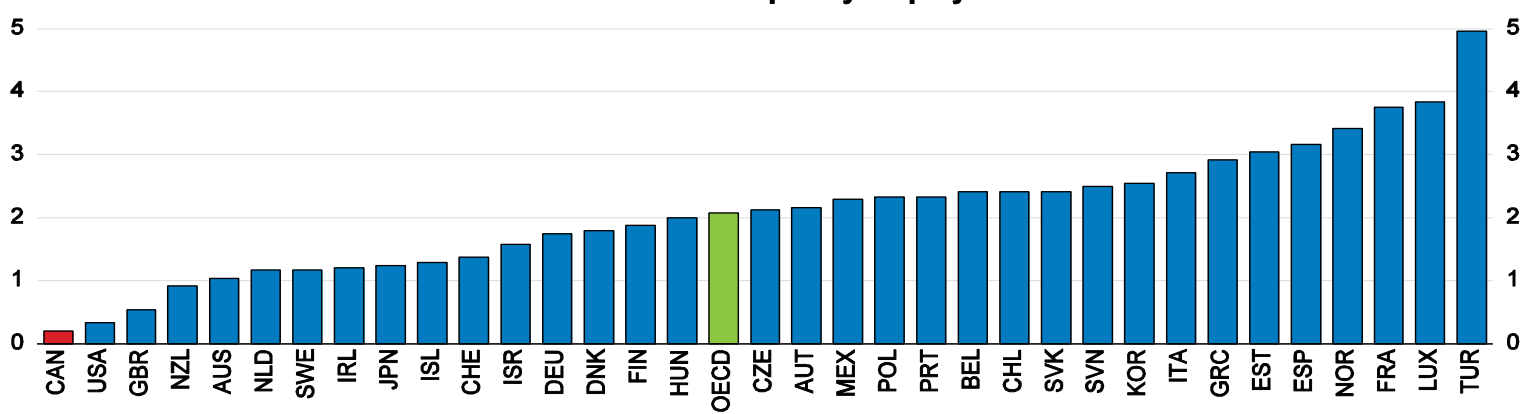

Source: OECD, Employment Protection Legislation database. 
Figure 10. Framework policies and resource flows to patenting firms, 2003-10

Estimated impact of various policies on the responsiveness of the firm employment/investment to patenting 1

\section{A. Additional labour attracted by a firm that increases its patent stock by $10 \%$}

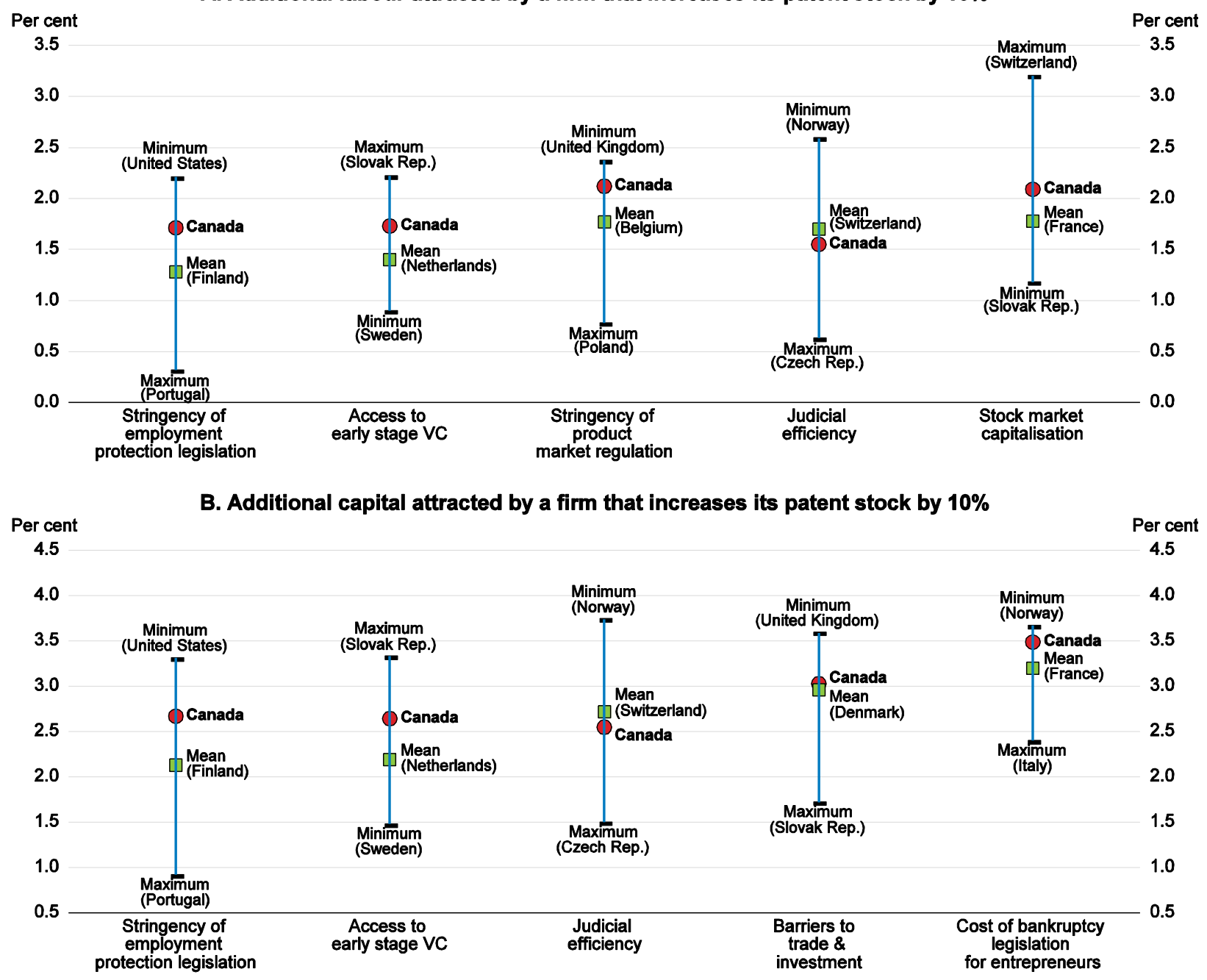

1. The chart shows that the sensitivity of firm employment and capital to changes in the patent stock varies according to the policy and institutional environment. To calculate the policy effects, coefficient estimates from Table 8 in Source are combined with the average values of the policy indicators for each country over the sample period. The label "Minimum" (the "Maximum") denotes the country with the lowest (highest) average value for the given policy indicator over the sample period.

Source: D. Andrews, C. Criscuolo and C. Menon (2014), "Do Resources Flow to Patenting Firms?: Cross-Country Evidence from Firm Level Data", OECD Economics Department Working Papers, No. 1127, OECD Publishing, Figure 4 updated with data for Canada.

\section{Focusing SME programmes more on clear market failures}

Canadian governments operate a number of programmes to support small businesses. At the federal level, the main programmes are aimed at facilitating small business financing, supporting research and development (R\&D) and innovation, and encouraging entrepreneurship (Table 2). Most of the estimated fiscal cost of these programmes at the federal level is attributable to preferential tax arrangements, the most important of which are the reduced income tax rate (relative to the standard corporate tax rate) for small, Canadian-controlled private corporations (CCPCs) (known as the Small Business Deduction (SBD) and the enhanced credits for SMEs under the Scientific Research and Experimental Development (SR\&ED) tax credit programme. Provincial governments enrich both of these programmes. 
As noted above, small business dynamism is not an end in itself but rather an indication that the SME sector is functioning in a way that contributes to overall productivity growth. Insofar as the objective of public policy is to increase living standards by facilitating higher productivity, small business programmes should address clear market failures efficiently (so that the marginal costs of correcting the market failure do not exceed the marginal benefits). In many cases, programmes that succeed in doing so will also increase small business dynamism. A review of the market failures that might warrant small business programmes from an economic point of view points to programmes that differ from some Canadian programmes, suggesting that there is scope to re-orient these programmes to address market failures more efficiently.

Figure 11. Venture capital investments are relatively high

As a percentage of GDP, 2014 or latest available year

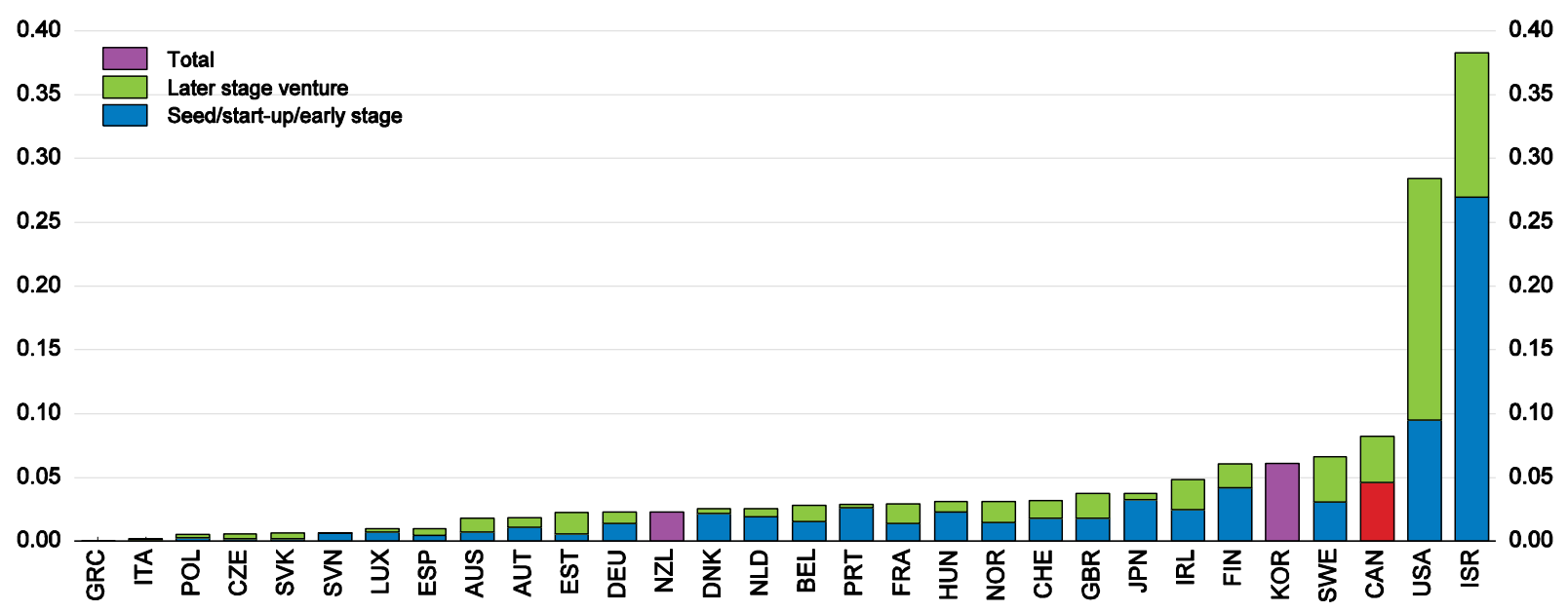

Source: OECD (2015), Entrepreneurship at a Glance 2015, Figure 7.1.

\section{Financing programmes}

The economics literature indicates that capital-market failures may result in SME financing being too high, too low or for the wrong projects (Box 2; Table 3). Results from economic models depend on the assumptions made. For example, Boadway and Keen (2006) show that with risk-neutral agents and only debt financing, asymmetric information (entrepreneurs and lenders each know less about the other party's true characteristics than the other party) results in too little financing of projects with low returns if successful and a high probability of success but too much financing of projects with the opposite characteristics (because entrepreneurs do not take into account the social costs from the relatively high chance that the loan will not be repaid). While no clear case for subsidising SME financing in general emerges, asymmetric information is more likely to result in underinvestment in young firms with innovative projects. First-time entrepreneurs, by definition, do not have a track record that will help secure financing and if the proposed project is difficult to understand, the impact of asymmetric information becomes much larger. Underinvestment in such firms is all the more likely considering the innovation spill-overs that they generate. 
Table 2. Federal tax and spending programmes that support small business and entrepreneurship ${ }^{1}, 2013^{2}$

\begin{tabular}{|c|c|c|c|}
\hline Policy & Description & Type of Support & Cost (CAD Million) \\
\hline Financing Programmes & & & 2836.6 \\
\hline $\begin{array}{l}\text { Preferential tax rate for small companies (Small } \\
\text { Business Deduction) }\end{array}$ & $\begin{array}{l}\text { Low rate of income tax on up to CAD } 500000 \text { of active business income; income limit } \\
\text { reduced to zero as taxable capital rises from CAD10 to CAD15 m. }\end{array}$ & SB & 3065.0 \\
\hline $\begin{array}{l}\text { Small Business Financing (Loan guarantee } \\
\text { programme) }\end{array}$ & $\begin{array}{l}\text { Government pays } 85 \% \text { of loan losses, capped at about } 12 \% \text { of value of portfolio. Fees } \\
\text { cover about } 70 \% \text { of programme costs. }\end{array}$ & SB & 59.2 \\
\hline \multirow[t]{6}{*}{ Business Development Bank of Canada (BDC) } & & & -432.6 \\
\hline & Financing--direct provision of non-investment grade loans & $S B$ & -433.8 \\
\hline & Subordinate financing--direct supply of higher risk instruments & $E$ & -23.3 \\
\hline & Venture capital programme & $E$ & 13.4 \\
\hline & Consulting -- below-cost provision of business advice & $E$ & 16.9 \\
\hline & Securitisation--promote asset-based financing by small financial companies & $S B$ & -5.8 \\
\hline $\begin{array}{l}\text { Labour-sponsored venture capital corporations } \\
\text { (LSVCCs) tax credit }\end{array}$ & $15 \%$ tax credit on up to CAD 5000 investment in LSVCCs. & $\mathrm{E}$ & 145.0 \\
\hline Other programmes targeted at small business & & & 409.6 \\
\hline Hiring Credit for small business & Reduction in employment insurance premiums & SB & 225.0 \\
\hline \multirow{3}{*}{ Spending programmes supporting small business } & Regional development & SB & 177.4 \\
\hline & Youth employment strategy & SB & 5.1 \\
\hline & Community futures programme & SB & 2.1 \\
\hline Support for R\&D and innovation & & & 1522.3 \\
\hline Enhanced SR\&ED Tax Credit & Higher refundable tax credit for R\&D small firms ( $35 \%$ vs $20 \%$ ) & SB & 1330.0 \\
\hline Industrial Research Assistance Programme & Subsidies and free advice for undertaking R\&D & $\mathrm{E}$ & 168.1 \\
\hline Digital Technology Adoption Programme & Subsidies and free advice for firms adopting digital technologies & $\mathrm{E}$ & 24.2 \\
\hline $\begin{array}{l}\text { Spending programmes supporting } \\
\text { entrepreneurship }\end{array}$ & Canadian Youth Business Foundation, Women's Enterprise Initiative & $\mathrm{E}$ & 14.9 \\
\hline $\begin{array}{l}\text { Non-targeted programmes supporting } \\
\text { entrepreneurship }\end{array}$ & & & 620.0 \\
\hline Lifetime Capital Gains Exemption & $\begin{array}{l}\text { Up to CAD } 750000 \text { capital gains tax exemption on disposition of shares in Canadian- } \\
\text { controlled private corporations. }\end{array}$ & $\mathrm{E}$ & 580.0 \\
\hline $\begin{array}{l}\text { Deduction of Allowable Business Investment } \\
\text { Losses }\end{array}$ & Capital losses deductible from ordinary income when they exceed realised capital gains. & $\mathrm{E}$ & 35.0 \\
\hline Rollover of investments & $\begin{array}{l}\text { Sales of small business shares do not trigger a capital gain if the proceeds are re-invested } \\
\text { in another small business. }\end{array}$ & $\mathrm{E}$ & 5.0 \\
\hline Total Support & & & 5403.40 \\
\hline Entrepreneurship (\% of total support) & & & $18.1 \%$ \\
\hline Small business (\% of total support) & & & $81.9 \%$ \\
\hline
\end{tabular}

1. Excluding agriculture and fishing.

2. Fiscal year 2013-14 for spending programmes. Legend: SB Small Business; E Entrepreneurship

Source: J. Lester (2016), "Policy Interventions Favouring Small Business: Rationales, Results and Recommendations", forthcoming; Department of Finance (2016), Report on Federal Tax Expenditures - Concepts, Estimates and Evaluations. 
Table 3. Rationales for government intervention to support innovative entrepreneurs

\begin{tabular}{|c|c|c|c|}
\hline Issue & Description & Impact & $\begin{array}{c}\text { Impact on } \\
\text { Entrepreneurs }\end{array}$ \\
\hline \multicolumn{4}{|l|}{ Financial market failures } \\
\hline Adverse selection & Quality of projects/entrepreneurs difficult to determine ex ante. & $\begin{array}{l}\text { Risk-neutral agents: overinvestment in innovative projects most likely outcome. } \\
\text { Risk-averse entrepreneurs: underinvestment in start-ups. }\end{array}$ & $\begin{array}{l}\text { Favourable } \\
\text { Unfavourable }\end{array}$ \\
\hline Moral hazard & cting in self-interest undermines efficiency. & Entrepreneurs undersupply effort and capitalists undersupply advice. & Unfavourable \\
\hline \multicolumn{4}{|l|}{ Externalities } \\
\hline R\&D / Process innovation & $\begin{array}{l}\text { Knowledge spillovers } \\
\text { Higher consumer surplus from lower costs } \\
\text { Destruction of incumbents' rents } \\
\text { "Innovation contests" }\end{array}$ & $\begin{array}{l}\text { All firms underinvest. } \\
\text { All firms underinvest. } \\
\text { All firms overinvest; larger impact for start-ups. } \\
\text { Dissipation of potential rents. Entry of new firms will occur too soon. }\end{array}$ & $\begin{array}{l}\text { Neutral } \\
\text { Neutral } \\
\text { Favourable } \\
\text { Favourable }\end{array}$ \\
\hline New products & Destruction of rents and higher consumer surplus are ignored. & $\begin{array}{l}\text { High correlation of entry and new products means entrants affected most; but the } \\
\text { impact of the offsetting influences is ambiguous. }\end{array}$ & Ambiguous \\
\hline Learning by doing & $\begin{array}{l}\text { Experience raises productivity; some of this knowledge may } \\
\text { spill over to other firms. }\end{array}$ & New firms bear the cost but cannot appropriate all the benefits, so entry is too slow. & Unfavourable \\
\hline Information & $\begin{array}{l}\text { Entry provides a signal of profitability that benefits other } \\
\text { firms. }\end{array}$ & New firms bear the cost but cannot appropriate all the benefits, so entry is too slow. & Unfavourable \\
\hline $\begin{array}{l}\text { Agglomeration or network } \\
\text { effects }\end{array}$ & Firms benefit from lower costs by co-locating. & $\begin{array}{l}\text { Entrepreneurial start-ups may have less flexibility in location choice, so may get } \\
\text { smaller benefit from agglomeration economies. }\end{array}$ & Unfavourable \\
\hline \multicolumn{4}{|l|}{ Labour market imperfections } \\
\hline Adverse selection & $\begin{array}{l}\text { Cannot determine quality of workers ex ante, so all in the pool } \\
\text { are offered the same rate. }\end{array}$ & $\begin{array}{l}\text { Marginal product of marginal employee exceeds wage rate; impact may be worse for } \\
\text { firms hiring workers for the first time. }\end{array}$ & Unfavourable \\
\hline Search externalities & $\begin{array}{l}\text { Employees and employers do not capture all of the benefits of } \\
\text { their search efforts. }\end{array}$ & Start-ups may expend more effort searching and pay higher wages. & Unfavourable \\
\hline \multicolumn{4}{|l|}{ Non-financial barriers } \\
\hline Incentive to innovate & Either entrants or incumbents may innovate too soon. & $\begin{array}{l}\text { Entrants ignore existing rents; incumbents attempt to prevent entry. Direction of bias } \\
\text { depends on timing and disruptiveness of innovation. }\end{array}$ & Ambiguous \\
\hline $\begin{array}{l}\text { Entry deterrence by } \\
\text { incumbents }\end{array}$ & $\begin{array}{l}\text { Incumbents have an incentive to overinvest in capital, } \\
\text { advertising and patenting. }\end{array}$ & Entry will be too low. Best policy response is to tax established firms. & Unfavourable \\
\hline Tax policy & $\begin{array}{l}\text { Asymmetric treatment of profits and losses } \\
\text { Asymmetric taxation of capital gains and losses } \\
\text { Calendar-year taxation with progressive rates } \\
\text { Profit-insensitive taxes - payroll, property taxes } \\
\text { Compliance costs }\end{array}$ & $\begin{array}{l}\text { Loss-making start-ups will pay a higher effective tax rate. } \\
\text { Discourages risk-taking. } \\
\text { Higher effective tax rate on "lumpy" returns. } \\
\text { Loss-making start-ups will be at a disadvantage. } \\
\text { Fixed costs put start-ups at a disadvantage. }\end{array}$ & $\begin{array}{l}\text { Unfavourable } \\
\text { Unfavourable } \\
\text { Unfavourable } \\
\text { Unfavourable } \\
\text { Unfavourable }\end{array}$ \\
\hline $\begin{array}{l}\text { The cc } \\
\text { policy }\end{array}$ & of this column are meant to indicate whether policy should & $\begin{array}{l}\text { courage, discourage or be neutral relative to entrepreneurship. In many cases } \\
\text { her than directly subsidising or taxing entrepreneurial effort. }\end{array}$ & first-best \\
\hline
\end{tabular}


ECO/WKP(2016)38

\section{Box 2. Capital market efficiency in the presence of asymmetric information ${ }^{1}$}

\section{Adverse selection}

Adverse selection arises when parties to a contract are less informed about the other party's true characteristics than $\mathrm{he} / \mathrm{she}$ is and assume that they are worse than revealed. While adverse selection may cause SME financing to diverge from the socially optimal level, it is not clear whether the result is too much or too little financing. Results from economic models depend on the assumptions made. Boadway and Keen (2006) exemplifies this point. The authors develop a model that generalises the previous literature to characterise the nature of credit-market inefficiency when the distribution of projects with respect to their return if successful $(R)$ and chance of success $(p)$ can take any form. With risk-neutral agents, they find that there will be underinvestment in projects with low $R$ and high $p$, and overinvestment in projects with high $R$ and low $p$ when only debt finance is available; in the former case, the relatively low $\mathrm{R}$ leaves the investor with too little in the good state, after payment of interest, but is enough from the social perspective given the high probability that the loan will be repaid and no monitoring costs incurred; in the latter case, projects have a return that is high enough in the good state to make the investment privately profitable but not high enough to compensate society for the relatively high chance that the loan will not be repaid and monitoring costs incurred. When only equity finance is available, they find that there is overinvestment. If entrepreneurs are offered the choice between equity and debt contracts, there is overinvestment if equity contracts are pooled and an ambiguous outcome if equity contracts are return-specific.

Braido et al. (2011) adapt the Boadway and Keen model to allow for risk-averse, wealth constrained entrepreneurs. When such entrepreneurs have access to both debt and equity financing with project pooling by outside investors, the Boadway-Keen overinvestment result (assuming risk-neutral agents) no longer holds. There is a distorted mix of projects financed and the total volume of projects financed may be higher or lower than what would occur in an efficient capital market, similar to the BoadwayKeen result for debt financing. This outcome reflects two market failures. As a result of adverse selection, some low-risk projects with negative social benefits are financed while as a result of risk-averse entrepreneurs some high-risk projects with positive social benefits are not undertaken. Using numerical analysis with plausible assumptions about the degree of risk aversion, the authors demonstrate that the net impact of the two market failures is likely to be too little investment in entrepreneurial projects. Hence, there may be a case for subsidising high-risk projects with potentially high returns, although it is not clear how such projects could be distinguished from others ex ante.

Boadway and Sato (1999) examine inefficiencies in financing when lenders incur costs to assess the probability of success of projects and use the results to set interest rates. To discourage entrepreneurs with lower quality projects from switching lenders, they offer a pooled interest rate on loans rather than a rate that reflects individual risk. As a result, ex ante evaluation costs will be recovered through higher interest rates on good quality loans, pushing them above their efficient levels. Furthermore, lenders experience a net gain by incurring monitoring costs to reduce errors in classifying projects. Assuming that it is easier to identify high quality than low quality projects, error correction will consist of shifting projects from higher to lower categories, resulting in higher interest rates on loans for lower quality projects. As the private gain to lenders will exceed the social gains, which is the sum of lenders' gains and borrowers losses, lenders have an incentive to allocate too many resources to ex ante assessment of project quality.

Dietz (2002) analyses adverse selection in models of equity financing that include advice provided by venture capitalists. Entrepreneurs with knowledge of the quality of their projects actively seek higher-cost venture capital financing for high-risk (low p), high return (high R) projects because they expect the advice provided will raise the net return by increasing the probability of success. Assuming that advice has a larger impact on higher risk projects than on lower risk projects, venture capitalists will also want to finance high-risk, high-return projects. High risk and the cost of providing advice drive the cost of venture capital finance well above that of "pure" (no advice) equity financing, so entrepreneurs with projects that have a probability of success above a certain threshold do not have an incentive to seek venture financing. If competition among venture capitalists reduces the cost of venture financing, the standard adverse selection problem arises. Some entrepreneurs with low-risk projects will have an incentive to switch from pure to venture equity financing because they will perceive a net benefit from higher cost financing accompanied by some advice. These lower-risk projects will not be profitable for venture capitalists. In the absence of screening, risky projects will pay too much for venture financing and less risky projects will pay too little.

Dietz highlights the fact that venture capitalists have an incentive to incur screening costs to eliminate the low-risk projects that cannot be profitably financed. Venture capitalists invest in screening until the marginal cost of screening equals the marginal benefit from raising the quality of projects financed. Venture capitalists bear all of the costs of screening but do not capture the benefit of avoiding wasteful spending by entrepreneurs on poor-quality projects. The investment in screening is therefore inefficiently low.

\section{Moral hazard}

Moral hazard entails a party to a contract behaving in an unobserved but prejudicial way to the other party after the contract has been signed. Investors wanting to protect their investment against hidden actions by entrepreneurs will structure contracts to align incentives of both parties and take an active role in managing the business. As pointed out by Elitzura and Gavious (2003), there is a "double" moral hazard problem in equity finance because both the entrepreneur and the venture capitalist contribute to the success of the project, but neither receives the full value of their contribution. As a result, the amount of business management services (advice) provided by venture capitalists is likely to be inefficiently low.

1. For a more in-depth discussion of these issues, see Lester (2016). 
The nature of market failures affecting young, high-growth-potential firms and hypothetical government interventions to offset them are summarised in Box 2. The following tentative conclusions about the nature of such efficient government intervention can be drawn:

- While adverse selection may affect all markets, the problems are likely to be severe enough to justify intervention only for those in which innovation is crucial.

- Loan-guarantee programmes should support the less risky innovative projects that can be financed by debt. Such projects require an above-average level of screening by lenders but are not suitable for venture capital financing, because outside advice would not appreciably affect their probability of success.

- Governments should subsidise basic advice to entrepreneurs. This could enhance welfare by preventing them from wasting resources on low-quality projects or by raising the probability of success of projects that are too risky for debt or pure equity financing but not risky enough to warrant venture financing.

- Risk aversion probably results in too little investment by start-up entrepreneurs. Policies to reduce risk aversion facilitate risk-pooling and increase the supply of seed capital could be welfare enhancing.

- Knowledge spill-overs result in underinvestment in the venture capital segment, while adverse selection probably results in overinvestment. Moral hazard yields under-provision of advice by venture capitalists, so policies that raise the incentive to provide advice without increasing the supply of government venture capital are probably welfare-improving.

Some of Canada's small business financing programmes already reflect these conclusions. However, the economic rationale for others, including some of the most costly, is weak. There is scope to reform them, so that they have a more favourable effect on productivity and well-being.

\section{Small Business Deduction}

The preferential tax rate for small companies (CCPCs) is intended to "provide small corporations with more after-tax income for reinvestment and expansion" (Finance Canada, 2010, p. 75). The federal small business deduction (SBD) entitles them to a 4.5 percentage point reduction in the general corporate income tax rate to $10.5 \%$ on the first CAD 500000 of active business income if their "taxable capital" does not exceed CAD 10 million; business income in excess of CAD 500000 is taxed at the standard corporate rate. Beyond the taxable capital threshold, the federal SBD is clawed back on a straight-line basis, with the eligible income limit reaching zero once capital exceeds CAD 15 million. Thus, marginal corporate tax rates on business income over CAD 500000 the eligible income limit can exceed the standard rate over the claw-back range, if it assumed that increased income necessitates investment of taxable income. The provinces have similar arrangements, although their corporate income tax rates and thresholds vary. Taking into account both federal and provincial arrangements, the weighted average small company tax rate in 2016 is $14.7 \%, 12$ percentage points lower than the general rate of $26.8 \%$ (includes rate changes at the provincial level announced before January 1, 2016). The new government announced in the 2016 federal budget that the further scheduled reductions in the small company rate are deferred.

Preferential tax rates for small companies are found in only 11 out of the 34 OECD member countries (12 countries had such arrangements in 2014 according to OECD (2015c), but the United Kingdom abolished its preferential rate from 1 April, 2015). Thresholds for withdrawing small company tax preferences are much lower in most other countries with such arrangements than in Canada. Small company tax rates in Canada were low by international comparison in 2014, especially over the EUR 100 $000-500000$ income range (Figure 12), and in absolute terms, at least, are now lower than in 2014. 
Figure 12. Progression of average statutory corporate income tax rates Selected OECD countries, 2014

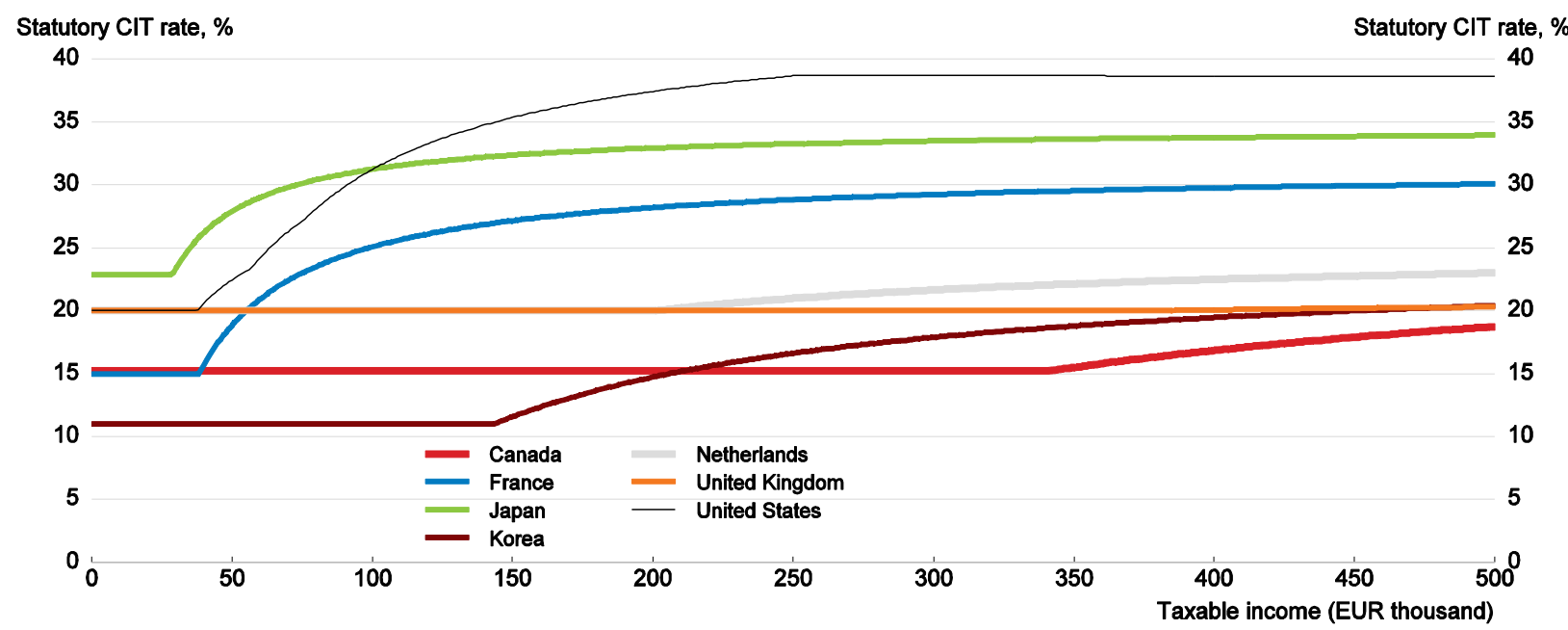

Source: OECD (2015), "Taxation of SMEs in OECD and G20 Countries", OECD Tax Policy Studies, No. 23, Figure 2.3.

SME owners who would be subject to the top personal income tax rate as sole proprietors or partners in their business have some opportunities to reduce their tax liabilities by incorporating. Income that is reinvested in the company increases the company's share value. When those shares are sold, only half of the capital gains on them are included in the personal income tax base. In 2014, the combined small corporate and top personal income tax rate on capital gains was $31 \%, 9$ percentage points lower than the combined rate under the basic corporate income tax rate and 19 percentage points lower than the top marginal rate on labour income (Table 4); if the capital gains had fallen within the lifetime personal capital gains tax exemption limit (see below), the combined rate would have been just the small company rate of $15.2 \%, 35$ percentage points less than the top personal rate on labour income.

Incorporation also provides opportunities for reductions in tax liabilities for business owners subject to the top marginal tax rate by distributing dividends to family members (other than minor children) with lower personal income tax rates.

The proportion of taxpayers benefiting from preferential taxation of small companies rises in a nonlinear fashion with personal income, reaching very high levels at the top end of the income distribution. Wolfson et al. (2014) report a rapidly rising share of taxpayers owning over $10 \%$ of the shares in at least one CCPC as taxable income rises beyond the top 5\%. They calculate that taking into account CCPC income raises the income share of the top $1 \%$ of taxpayers by about one-quarter and implies that it has been increasing at a noticeably faster rate in recent years than when only incomes based on individual tax returns are considered. Bazel and Mintz (2016) estimate that almost 60\% of the benefit of the SBD goes to individuals in the pre-2016 top personal income tax bracket (over CAD 150000 ).

Preferential small business tax schemes result in steeper increases in marginal effective tax rates on investment as firms grow beyond the thresholds for the preferences, potentially inhibiting growth. Using 2010 values for the standard corporate tax rate, the preferential small company rate, dividend taxes, capital gains taxes and personal income tax rates, Chen and Mintz (2011) find that marginal effective tax rates rose from $18 \%$ for the smallest companies to $27.5 \%$ when capital reached CAD 10 million, beyond which they jumped to $35 \%$ as the preferential small company rate begins to be phased out (Figure 13); their methodology is summarised in Box 3. They then stabilised until capital reaches CAD 36 million, at which point the entrepreneur is assumed to have exhausted his/her lifetime exemption of capital gains tax (which was CAD 750000 in 2010) and therefore must pay capital gains tax. 
Table 4. Labour tax rate, employee SSCs ${ }^{1}$ and combined statutory rates on dividends under basic and small business taxation, 2014

\begin{tabular}{|c|c|c|c|c|c|c|}
\hline & \multicolumn{2}{|c|}{ Top marginal rate on labour } & \multicolumn{2}{|c|}{$\begin{array}{c}\text { Combined corporate and } \\
\text { personal rates on dividends }\end{array}$} & \multicolumn{2}{|c|}{$\begin{array}{l}\text { Combined corporate and personal } \\
\text { rates on capital gains }\end{array}$} \\
\hline & $\begin{array}{l}\text { Excl. SSCs } \\
(\%)\end{array}$ & $\begin{array}{l}\text { Employee } \\
\text { SSC } \\
\text { differential } \\
\text { (\% points) }\end{array}$ & $\begin{array}{l}\text { Combined } \\
\text { rates under } \\
\text { basic CIT } \\
\text { rates (\%) }\end{array}$ & $\begin{array}{l}\text { Reduction in } \\
\text { combined rates } \\
\text { due to small } \\
\text { business CIT rates } \\
\text { (\% points) }\end{array}$ & $\begin{array}{l}\text { Combined } \\
\text { rates under } \\
\text { basic CIT } \\
\text { rates (\%) }\end{array}$ & $\begin{array}{l}\text { Reduction in } \\
\text { combined rates due } \\
\text { to small business } \\
\text { CIT rates ( } \% \text { points) }\end{array}$ \\
\hline Australia & 47 & & 47 & & 42 & \\
\hline Austria & 50 & & 44 & & 39 & \\
\hline Belgium & 45 & 14 & 51 & -7 & 34 & -9 \\
\hline Canada & 50 & & 51 & -2 & 40 & -9 \\
\hline Chile & 40 & & 40 & & 21 & \\
\hline $\begin{array}{l}\text { Czech } \\
\text { Republic }\end{array}$ & 15 & 11 & 31 & & 19 & \\
\hline Denmark & 56 & & 56 & & 48 & \\
\hline Estonia & 21 & 2 & 21 & & 33 & \\
\hline Finland & 49 & 8 & 42 & & 39 & \\
\hline France & 54 & 1 & 64 & -10 & 54 & -14 \\
\hline Germany & 47 & & 49 & & 44 & \\
\hline Greece & 46 & & 33 & & 26 & \\
\hline Hungary & 16 & 46 & 32 & -8 & 19 & -9 \\
\hline Iceland & 44 & & 36 & & 32 & \\
\hline Ireland & 51 & 4 & 55 & & 44 & \\
\hline Israel & 50 & & 49 & & 38 & \\
\hline Italy & 48 & & 46 & & 42 & \\
\hline Japan & 51 & 0 & 50 & -11 & 42 & -13 \\
\hline Korea & 39 & 4 & 51 & -9 & 24 & -13 \\
\hline Luxembourg & 44 & 1 & 43 & -1 & 29 & -1 \\
\hline Mexico & 35 & 0.3 & 42 & & 30 & \\
\hline Netherlands & 50 & 3 & 44 & -4 & 39 & -4 \\
\hline New Zealand & 33 & & 33 & & 28 & \\
\hline Norway & 39 & 8 & 47 & & 37 & \\
\hline Poland & 21 & 18 & 34 & & 31 & \\
\hline Portugal & 50 & 11 & 51 & & 44 & \\
\hline $\begin{array}{l}\text { Slovak } \\
\text { Republic }\end{array}$ & 22 & 13 & 33 & & 33 & \\
\hline Slovenia & 39 & 22 & 38 & & 20 & \\
\hline Spain & 52 & & 49 & -4 & 44 & -4 \\
\hline Sweden & 57 & & 45 & & 40 & \\
\hline Switzerland & 36 & 6 & 37 & & 21 & \\
\hline Turkey & 36 & & 34 & & 20 & \\
\hline $\begin{array}{l}\text { United } \\
\text { Kingdom }\end{array}$ & 45 & 2 & 45 & -1 & 38 & -1 \\
\hline United States & 46 & 2 & 60 & 0 & 49 & -1 \\
\hline $\begin{array}{l}\text { Unweighted } \\
\text { mean }\end{array}$ & 42 & 8 & 44 & -2 & 35 & -2 \\
\hline Median & 46 & 5 & 44 & -2 & 37 & -4 \\
\hline
\end{tabular}

1. See notes to Table 2.6 in Taxation of SMEs in OECD and G20 Countries", OECD Tax Policy Studies, No. 23, Paris.

Source: OECD (2015), "Taxation of SMEs in OECD and G20 Countries", OECD Tax Policy Studies, No. 23, OECD Publishing, Paris, Table 2.6. 


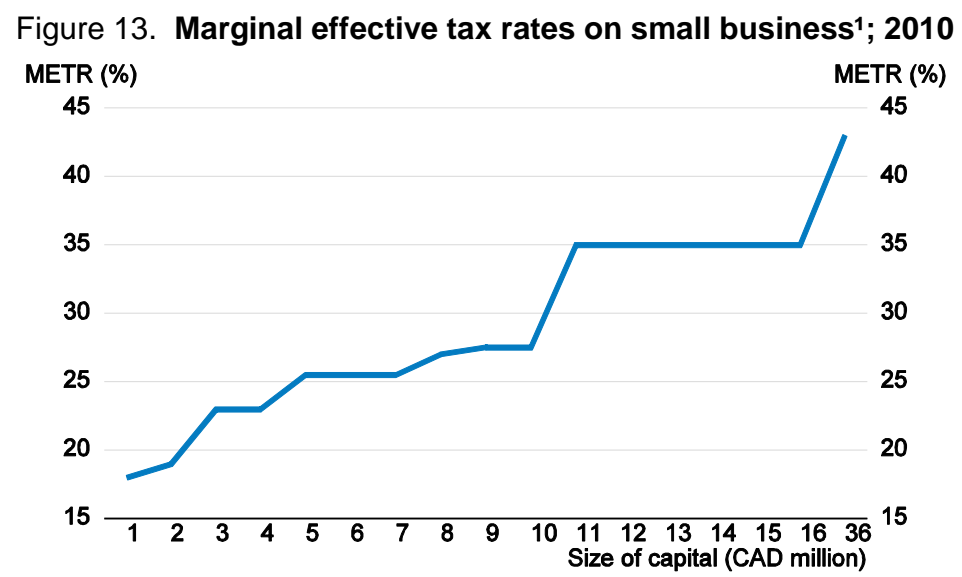

1. Base case: $5 \%$ pre-tax profit-to-asset ratio; $29 \%$ debt-to-asset ratio; and $40 \%$ dividend pay-out ratio.

Source: D. Chen and J. Mintz (2011), "Small Business Taxation: Revamping Incentives to Encourage Growth", University of Calgary School of Public Policy Research Papers, Vol. 4, Issue 7, May.

\section{Box 3. Calculating marginal effective tax rates on small-firm investment}

The marginal effective tax rate (METR) is the wedge between the pre-tax $(R)$ and after-tax $(r)$ rate of return on capital that an investor has to receive to justify making an investment, expressed as a percentage of the pretax rate of return:

$$
\text { METR }=(R-r) / R
$$

To calculate the METR for small-firm investments, it is necessary to take into account personal income taxes on dividends and capital gains because entrepreneurs provide most equity finance in small companies and typically obtain debt finance from lending institutions; by contrast, it is not necessary to take Canadian personal tax rates into account to calculate METRs for large firms, because these taxes only have a small effect on the cost of debt and equity financing, as Canada accounts for only a small share of such capital raised in international markets. Two special features of personal income taxes are important to note: first, as pointed out above, dividend tax credits are lower for "ineligible" dividends paid out of profits taxed at the reduced small business tax rate than for "eligible" dividends paid from profits taxed at the general corporate tax rate; and second, there is an indexed lifetime capital gains tax exemption that is capped (the first CAD 813600 of gains were exempt in 2015) for realised capital gains on qualifying shares held in CCPCs, most of which are small companies.

For the METRs that Chen and Mintz (2011) calculate in the base case, it is assumed that an entrepreneur invests his/her savings in the equity of the business and that debt is provided by banks and other lending institutions. An entrepreneur invests in equity until the marginal after-tax rate of return on investment equals the risk-adjusted after-tax return that could be earned on alternative investments. As taxation of the entrepreneur's equity investment returns rises, the required pre-tax rate of return also rises, reducing the amount of investment in the business that is profitable to undertake. The cost of debt finance is the market interest rate charged by banks and other lenders. In their base case, the pre-tax profit ratio is $5 \%$, the debt-to-asset ratio is $29 \%$ and the dividend pay-out ratio is $40 \%$; these ratios are based on Statistics Canada data for firms with revenue under CAD 5 million in 2004-06 (representing the vast majority of small businesses).

However, Finance Canada (2013) finds that the effect of rising tax rates is more on tax planning strategies than on real economic activity. This study finds that there is an increased concentration of small companies at or just below the profit limits for the SBD (CAD 200000 in 2000, CAD 400000 in 2007 and CAD 500000 in 2011) (Figure 14, Panel A). This concentration and its movement over time suggest that small company owners have some flexibility over the timing and form of distributions from their company. For example, Finance Canada (2013) points out that in 2000 it would have been more profitable for a small 
firm owner facing a personal marginal income tax rate of less than $45 \%$ to increase his/her wages instead of accruing profits just beyond the CAD 200000 threshold, which would have been taxed at $45 \%$. By contrast, there is no concentration of firms at the taxable capital thresholds for clawing back the SBD (Panel B). "This suggests that the concentrations observed ... at the levels of taxable income at or just below the business limit are likely the result of tax planning, rather than changes in real economic decisions" (Finance Canada, 2013, p. 63).

Figure 14. The SBD does not alter incentives to grow but encourages tax planning

Number of small CCPCs ${ }^{1}$ claiming the federal small business deduction (SBD)

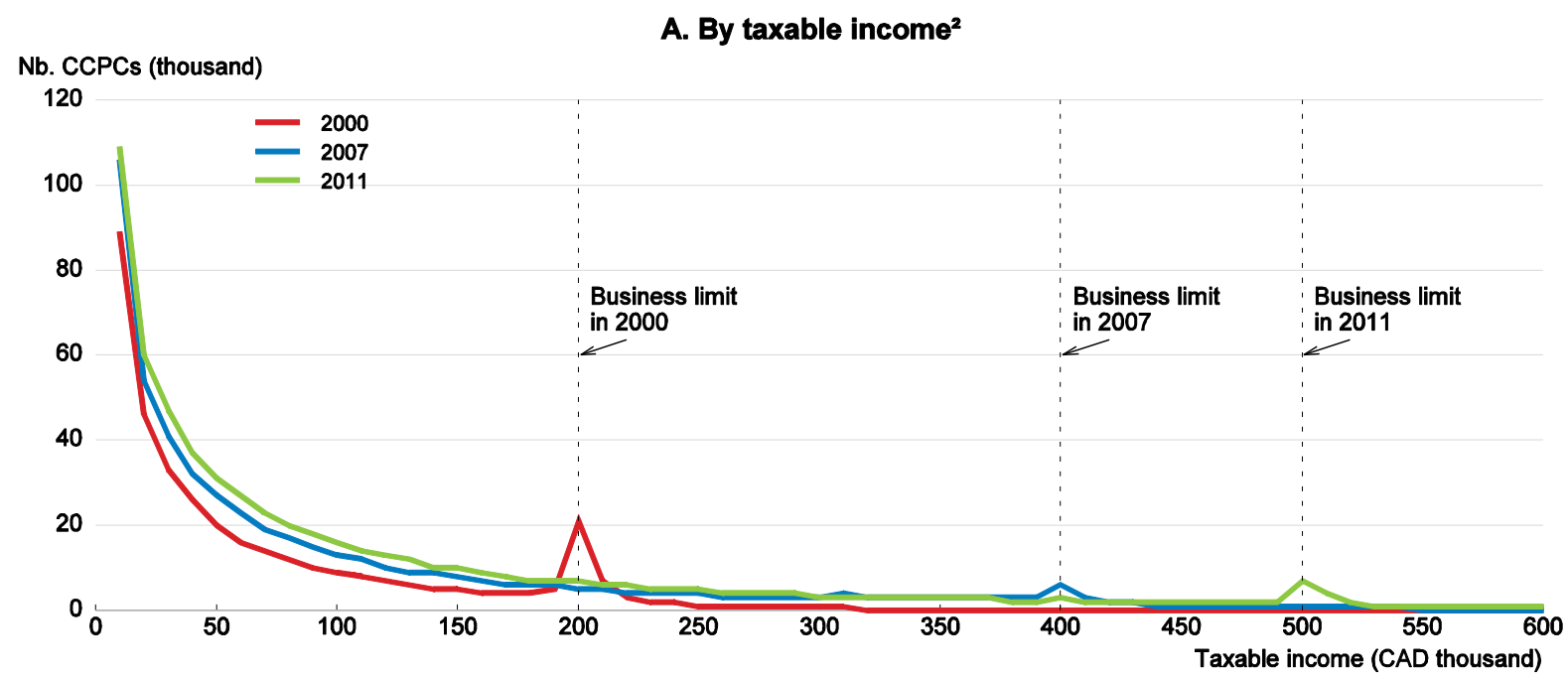

B. By taxable capital ${ }^{3}$

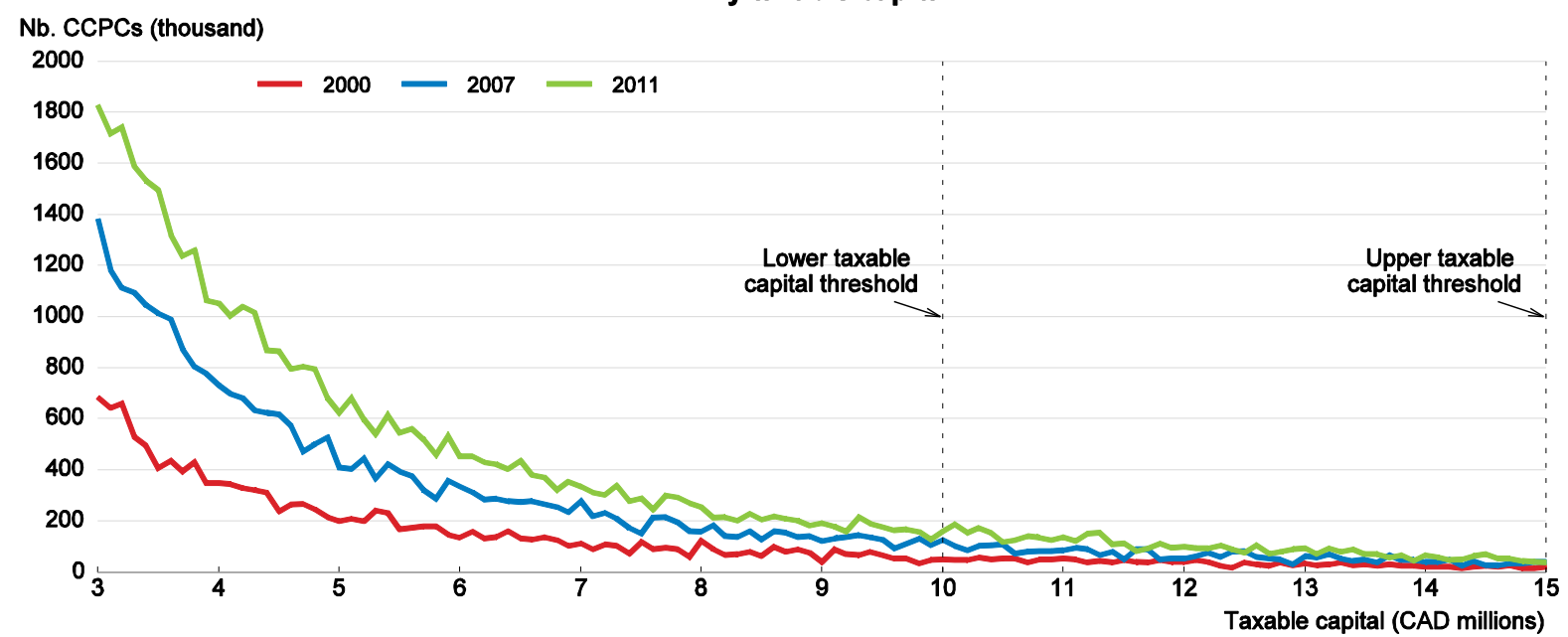

1. Small Canadian-controlled private corporations (CCPCs) that are part of an associated group of corporations are shown on the chart based on the group's total taxable income/capital.

2. Labels on the horizontal axis indicate the upper end-point of each taxable income class.

3. Labels on the horizontal axis indicate the mid-point of each taxable capital class. Only CCPCs with taxable capital between CAD 3-15 million are shown to facilitate the presentation. The vertical lines indicate the beginning and end of the range of taxable capital over which the business limit is phased out.

Source: Department of Finance Canada (2013), "Tax Expenditures and Evaluations 2012: Part 2 - Taxation of Small Businesses in Canada", Charts $5 \& 6$. 
As discussed above, the economic literature on capital market failures does not establish a case for subsidising SMEs based on their size alone. Adverse selection can result in over- or underinvestment (see Box 2); however, there is a case for helping young firms with innovative projects, as adverse selection is much more likely to result in underinvestment in such cases. In the Mirrlees Review of taxation in the United Kingdom (Mirrlees et al., 2010), it was concluded that there was no evidence of any general capital market failure affecting small firms (Crawford and Freedman, 2010). Accordingly, there was no case for a reduced small business corporate tax rate - this tax preference was abolished on 1 April 2015. The principal finance gap in the United Kingdom was for new and start-up businesses (Graham, 2004), and this could be more effectively addressed through targeted measures. Freedman (2009, p. 172) reports to the Henry Tax Review in Australia that "as a result of these findings, there has been an attempt to target tax assistance in raising external finance to those firms that do experience a problem, through the Enterprise Investment Scheme, Venture Capital Trusts and the Corporate Venturing Scheme...non-tax-based assistance is given through the Small Firms Loan Guarantee, which has been remodelled following the Graham review to focus on firms within their first five years of business rather than on small firms generally." She adds that "this is consistent with the position taken here that the focus should not be on size but on other characteristics."

The Canadian government already operates a number of schemes that are more specifically targeted at capital market failures than the preferential tax rate for small companies, notably through the Business Development Bank of Canada (BDC) and venture capital programmes (see below). In view of the findings of the Mirrlees and Henry tax reviews in the United Kingdom and Australia, respectively, the Canadian government should in turn conduct its own review of small business support to identify capital market failures and the policy instruments best suited to addressing them.

Another rationale for the preferential tax rate for small companies could be that it compensates them for higher tax and regulatory compliance costs. This might be valid in some cases, but less so for larger firms that qualify as they are big enough to have significant economies of scale in these costs. On average, Industry Canada (2013) estimates the "regulatory bill" to have been CAD 3500 per SME business (establishments with fewer than 500 employees and annual gross revenues between CAD 30000 and CAD 50 million) in 2011, corresponding to $0.29 \%$ of business-sector revenues.

\section{Programmes to increase lending to small businesses}

The federal government also operates a number of programmes to increase lending to small businesses either directly or through the government-owned Business Development Bank of Canada (BDC). The largest such programmes are the BDC's Financing Program, which makes non-investment grade loans, and Innovation, Science and Economic Development Canada's Small Business Financing Program (SBFP), which guarantees loans originating in the private sector.

\section{BDC Financing Program}

The BDC's mandate is to provide services complementary to those offered by commercial banks (Government of Canada, 1995). Its largest business line is the Financing Program, with a loan portfolio of CAD 18.4 billion in 2014. The BDC reports that the Financing Program provides loans to SMEs with a higher average risk profile than those offered by commercial banks, although no explicit comparison is provided. The allowance for credit losses was $2.8 \%$ of the loan portfolio in 2015 . The BDC reports that it made a profit of CAD 434 million on the Financing Program in 2013-14 (see Table 2). However, this result does not allow for the opportunity cost of the BDC's capital. Jenkins and Kuo (2007) recommend using an $8 \%$ real rate of return for the economic opportunity cost of capital in Canada based on what could have been earned had the funds been invested elsewhere in the economy. Using this estimate, Lester (2016) estimates that the Financing Program had a net cost of CAD 919 million in 2013-14. 
It is not clear what, if any, market failures this programme is intended to address. High-risk borrowers are not necessarily denied external finance by the private sector because of a capital market failure - it may be simply that the risk-adjusted expected returns on their projects are too low to be worth financing. This programme should be refocused to target clear capital market failures. As discussed above, this would be likely to entail focusing lending on start-ups and young firms, especially with innovative projects, as such firms' access to external finance is likely to be sub-optimal owing to asymmetric information. It may also be worth considering whether this assistance could be delivered more efficiently as a loan guarantee programme instead of by direct lending by a public bank. With weaker incentives to maximise profits, there is a risk that a public bank is not as good at assessing risk as private-sector banks.

\section{Small Business Financing Program}

SBFP is another generally available programme, under which the federal government guarantees loans originating in the private sector. Lester (2016) estimates that the value of outstanding loans in fiscal 2014 was CAD 4 billion. In order to participate in the programme, lenders must offer variable-rate loans at no more than $3 \%$ above the prime rate for business loans and fixed-rate loans at their single-family residential mortgage rate plus $3 \%$. These rates include a $1.25 \%$ annual administration fee paid to the federal government. Lenders also collect a $2 \%$ registration fee on its behalf. The government pays $85 \%$ of losses on defaulted loans, but for large lenders total default claims cannot exceed 12\% (10\% until 2009) of the value of the loan portfolio. In 2014, the cost of the SBFP net of fees collected was modest (see Table 2).

In fiscal 2014, the total value of new loans registered with the federal government was CAD 853 million, trending down from about CAD 1 billion in 2011 (Industry Canada, 2014a). Borrowers are predominantly young and small firms: $60 \%$ of participating firms were less than a year old and about $40 \%$ had less than CAD 500000 in annual turnover. The number of loans guaranteed that year was 5622, which was half the number registered in 2005. Lender dissatisfaction with profitability and the administrative effort required to register loans and process claims appears to have hurt use of the programme (Industry Canada, 2014b). Limits on the size of loans may also have been an issue, but they were increased in 2014. The 2015 budget increased the loan amount and maximum term for investment in real property and raised the size eligibility criterion for participation in the programme.

The latest evaluation of the SBFP (Industry Canada, 2014b) suggests that large banks typically pool all applicants rather than price loans to risk. All applicants with a credit score above a certain value are offered credit. Without a guarantee, applicants with a credit score below the cut-off would be denied credit rather than offered a loan at a higher rate. Because of adverse-selection effects, a rise in the "pooled" loan rate would be likely to reduce the average quality of applicants, causing a reduction in profits. With a loan guarantee, higher-risk borrowers gain access to credit without affecting the quality of borrowers in the original pool.

The incrementality of the SBFP is assessed on a periodic basis, using both survey and econometric analysis. The most recent survey of lenders (R. A. Malatest and Associates, 2014) reports that $46 \%$ of SBFP participants would have been rejected for a conventional loan. A further $30 \%$ would have been offered credit but on less favourable terms, such as additional collateral or a lower loan amount. Seens and Song (2015) develop a credit-scoring model similar to those used by banks. The model provides a satisfactory prediction of bank approvals of applications for conventional loans. When the model is applied to SBFP participants in 2011, it predicts that $67 \%$ of participants would have been refused a conventional loan. 
The large proportion of young firms among the beneficiaries of this programme suggests that it may be addressing capital market failures. It could be more effective in doing so if there were also an explicit focus on supporting innovative firms.

\section{BDC Growth and Transition Capital}

The BDC's Growth and Transition Capital programme targets high-potential firms that need financing to sustain growth or to transition between owners (BDC, 2015). As such, it is clearly intended to address a capital market failure. The programme makes debt and some equity-like investments that have subordinate status relative to other debt issued by firms receiving financing, making these investments riskier than loans made under the Financing Program. Reflecting this risk profile, interest income is high, amounting to 9.3\% of the portfolio, compared with 5.4\% for the Financing Program.

All of the financing activity takes place via joint ventures with the Caisse de dépôt et placement du Québec. The BDC acts as a general partner, handling all lending and managerial activities in exchange for fees (BDC, 2004). In 2014-15, the value of the stock of Growth and Transition Capital programme investments was CAD 643 million.

This programme can be expected to be of particular interest to entrepreneurs with projects that are too risky for conventional debt finance but that do not have a high enough return if successful to attract venture capital. Getting these borrowers into the appropriate financing niche could be welfare-enhancing. On the other hand, the programme will also be attractive to entrepreneurs with projects too risky for conventional debt finance for which they believe, rightly or wrongly, that advice from venture capitalists will not increase the probability of success sufficiently to cover the extra cost of venture capital financing. If these entrepreneurs are correct in their assessment, obtaining financing could be welfare enhancing; but if they are not, obtaining subordinated financing could impose a social cost in the form of wasted resources in a failed project.

Growth and Transition Capital may be filling a gap in the supply of risk capital by providing financing for projects too risky for conventional debt but not suitable for venture capital financing. It would be worth assessing if more resources should be allocated to screening and advising loan applicants. It is also not clear why the BDC should take the lead in its partnership with the Caisse. The possibility of providing side-car funding, where specialist investors would make decisions on where and how to supply subordinated loans on behalf of the BDC, should be investigated.

\section{Programmes to support venture capital}

There is a case for public support for venture capital investments on the grounds that they generate knowledge spill-over benefits that are not taken into account by investors. Lerner (2010) reports that venture capital generates three times as much innovation as an equal amount of corporate research and development. The key to success is finding instruments that increase the quantity of venture capital without diminishing its quality.

BDC Capital Inc.

The BDC is also an important player in the venture capital market. BDC Capital Inc. makes venture capital investments directly at every stage of a technology-based company's development and makes indirect investments via funds, some of which are led by private- and other public-sector funds. In fiscal years 2013-14 and 2014-15, new investments amounted to CAD 664 million, which was about 17.5\% of the value of all new risk capital investments, up from only $9 \%$ in the preceding three years. In 2015, BDC's 
venture capital portfolio (CAD 710 million) was split roughly 55-45 in favour of direct investments, down from $85-15$ in 2010.

A 2011 review of the industry and BDC's role in it concluded that the Canadian venture capital industry was "broken" (BDC, 2011, p. 9). The venture capital market shrank dramatically after the "dot.com" bust and fell further by 2010 as negative returns prompted private investors to exit the industry. According to the BDC, substantial changes would be required to draw them back (BDC, 2011). The review drew attention to the small scale of Canadian funds and the reduced skill of fund managers compared to their US counterparts as key reasons for industry underperformance. It also noted that substantial investments were made by government and retail funds (especially Labour Sponsored Venture Capital Corporations (LSVCCs)) that have objectives and face constraints that may hurt returns.

The 2011 report announced a new strategic direction, the most important element of which was the intention to use BDC resources to promote the emergence of "at-scale" funds managed by skilled personnel, emphasising indirect rather than direct investments. This approach implies an increasingly passive and smaller role for BDC as private-sector managers become more skilled, which should be beneficial as the quality of managers improves and the funds they work with grow.

Based on the policy conclusions summarised above, some suggestions to improve outcomes can be made:

- The BDC should shift from direct seed-capital investments to passive or side-car investments with angel investors. In this approach, the government would offer private investors leveraged returns by capping its return while leaving its entire investment at risk. The cap would be set so that the expected private return would rise by an amount equal to the estimated premium required by risk-averse entrepreneurs. As the risk premium and the proportion of the subsidy that will be passed on to entrepreneurs are unknown, the BDC should experiment with relatively small subsidies to gain some understanding of the market.

- If the BDC's 2011 review was right that there is a shortage of angel investors with enough industry knowledge to provide useful advice, it could continue to make direct investments at the same time as side-car investments. A comparison of rates of return obtained in the two approaches would provide a useful test of the shortage hypothesis.

- BDC's activity in the venture capital segment should be confined to indirect investment, with the private sector taking the lead in most circumstances. These passive investments should offer leveraged returns to its partners to expand the supply of venture capital to the extent warranted by knowledge externalities and to mitigate the moral hazard problem of venture capitalists providing less than the socially optimal amount of advice.

- The BDC should increase the supply of venture capital cautiously when implementing its strategy to restructure the industry. Considerable judgement will be required to get the right balance between the strategy's short-run costs and long-run benefits.

The federal government's Venture Capital Action Plan

The federal government announced the Venture Capital Action Plan (VCAP) in January 2013 to boost the venture capital industry. The VCAP is a package of both direct and indirect investments in the sector amounting to CAD 400 million over the following seven to ten years focused on later-stage financing. A key component of the Plan is the establishment of up to four large-scale funds of funds with private-sector investors and interested provinces, managed by BDC Capital Inc. through private-sector general partners. 
The VCAP funds of funds are structured to attract private investors to the asset class, including through the use of incentives, with each dollar in government capital attracting two dollars in private-sector capital.

\section{Labour-sponsored venture capital funds}

Canadian governments have also been aiming to encourage venture capital investments through socalled Labour-Sponsored Venture Capital Corporations (LSVCCs). The share of venture capital investments accounted for by LSVCCs has fallen markedly in recent years, from around $30 \%$ in 2006 to $4 \%$ in 2014, reflecting poor returns and the phasing out of LSVCC tax credit programmes (Industry Canada, 2014c and 2007). In this model, individuals investing in a fund formally sponsored by a union or an organisation affiliated with organised labour are eligible for a capped personal income tax credit provided that various conditions are met: the fund must issue common shares that are only available for purchase by retail investors, similar to a mutual fund; retail investors must hold their investments in the fund for at least eight years; and the fund must invest a minimum portion (usually 60\%) of its capital in firms with less than CAD 50 million in capital and must also commit for at least eight years. While it is not obvious why government-sponsored venture capital should be tied to organised labour, this feature may not have much effect insofar as unions "merely rent their name to LSVCCs without providing any additional governance over the funds' operations" (Cumming, 2007a, p. 2).

This structure contributes to poor performance. Small, retail investors are costly to service and rarely have the expertise required to become well informed. In these circumstances, no one has the ability or incentive to control managers. Moreover, even if small LSVCC investors wanted to sanction fund managers by exiting, they could not, owing to the lock-in. By contrast, investors in private venture capital funds are typically institutional investors, like pension funds, and high net worth individuals who have the incentive and ability to become well informed and control managers. Statutory constraints on LSVCCs, which are similar in each province that has LSVCC-type tax credits, further undermine performance (Cumming and MacIntosh, 2004). These include requiring investments to be made in the sponsoring jurisdiction and the reinvestment of fixed percentages of contributed capital in private companies raising venture capital within a stated period (usually one to three years). These constraints limit investment opportunities and at times oblige LSVCCs to make inferior investments (Cumming and MacIntosh, 2006). By contrast, restrictive covenants on private venture capital vary depending on the agreed needs of fund investors and the fund manager, which enables the limited and general partners to design covenants that are best suited to the fund's particular objectives.

LSVCC returns have been extremely low: for example, the five-year return as of 2006 was negative for most funds (Cumming, 2007a); a more recent analysis of retail venture capital corporation funds (including LSVCC funds) sponsored by and operating in British Columbia revealed five-year losses of 1157\% excluding the tax rebate (Brander et al., 2012). In other words, in the absence of the tax breaks, these funds would not be able to attract capital.

Not surprisingly, the tax breaks are the key selling point of LSVCCs (Cumming and MacIntosh, 2007). Most individuals invest in LSVCCs through individual registered retirement savings plans (RRSPs), thereby qualifying for tax savings over and above the tax credits (15\% capped at CAD 750 from the federal government with provinces typically matching this credit) (Cumming and MacIntosh, 2004). Combined with deductibility of contributions to RRSPs, the initial return from tax savings rises with the taxpayer's marginal income tax rate, reaching $400 \%$ on a CAD 5000 investment for an individual subject to a $50 \%$ marginal income tax rate ((5000 - out-of-pocket cost of 1000)/out-of-pocket cost of 1000).

Brander et al. (2008) find that government venture capital, which includes LSVCCs, has underperformed private venture capital in Canada in terms of both private value creation and public welfare for a number of reasons. First, government venture capital underperforms private venture capital in 
creating economic value: firms funded by government venture capital are less likely to have successful exits, are much less likely to have IPOs on major exchanges and generate lower exit values when they do have a successful exit. In addition, firms financed by government venture capital are more likely to go out of business over the investment time horizon and less likely to attract US investment, which can be important for linking into cutting-edge global networks. Second, firms funded by government venture capital are less likely to generate innovations, as measured by patents (even after controlling for industry selection). Third, the underperformance of firms funded by government venture capital reflects less effective mentoring and other value-adding skills, rather than the selection of lower-potential firms. Finally, government venture capital is crowding out private venture capital to a considerable but not complete extent. In other words, government venture capital is mostly investing in businesses that otherwise would have been funded by private venture capital and had more valuable treatment effects. As Lerner (2010, p. 262) stated, "[LSVCCs] not only backed incompetent groups that did little to spur entrepreneurship, but [they] crowded out some of the most knowledgeable local investors."

In light of poor government venture capital performance based on both private and social returns, the federal Labour Sponsored Venture Capital Corporation tax subsidy should be phased out, as previously planned, and greater use of more effective means of supporting venture capital should be explored. As noted above, one such promising approach, as was the case with the Venture Capital Action Plan (BDC Capital Inc. represents the government as an investor) and a number of provincial VC funds (e.g., the Ontario Venture Capital Fund and Quebec's Tarlys Capital), is to establish funds that operate like private, independent, limited partnership venture capital funds, with the government matching private investments in the funds. With this approach, the private partners select investments and provide monitoring and valueadded services. Typically, the government investor leverages returns for the private investors by not sharing fully in the profits if the firm is successful but fully sharing in losses otherwise.

Considerable experience has been gained with this approach through the US Small Business Innovation Research (SBIR) Program and Australia's Innovation Investment Funds (IIFs). Lerner (1999) finds that early-stage companies financed by SBIRs have substantially higher growth rates than non-SBIRfinanced companies. Cumming (2007b) finds that Australian IIFs are fostering the development of its venture capital industry in a statistically and quantitatively significant way. In implementing such programmes in Canada, it would be important to ensure that they are not limited to Canadian investors and firms, since the trend in venture capital is away from being 'local generalists' to becoming 'global specialists' (Brander et al., 2012). To remain competitive, Canadian venture capitalists are increasingly likely to require a global, or at least North American, investment reach.

\section{Advice and service coordination programmes}

\section{BDC Consulting Services}

The BDC also provides a broad range of advisory services to entrepreneurs at subsidised rates. The percentage of costs recovered through fees has been on a downward trend since 2010; in 2015 the cost recovery rate was $41.3 \%$, a bit more than half its value in 2010. A further decline is expected for fiscal 2016.

Providing consulting services at below-cost rates could be efficient. As discussed above (see Box 2), moral hazard in equity finance may result in a sub-optimal amount of business management services (advice) provided by venture capitalists, because they must share the value of this contribution with entrepreneurs (Elitzura and Gavious, 2003). Moreover, adverse selection in equity finance may result in venture capitalists underinvesting in screening, because they do not capture the full benefit of avoiding wasteful spending by entrepreneurs on low-quality projects (Dietz, 2002). Subsidised technical advice could also raise the probability of success of projects rejected by venture capitalists on the grounds of low 
returns but which are too risky for debt or pure equity financing (i.e. provided without advice). These benefits would arise from assisting entrepreneurs applying for subordinate financing, venture capital financing and a small slice of Financing Program clients. There is a plausible case for providing subsidised business management advice to potentially high-impact entrepreneurs. Such entrepreneurs may fail in the absence of such advice, so such a service can be seen as indirectly subsidising knowledge creation.

A new federal programme to help high-impact firms scale up

The 2016 budget proposes to launch a new initiative in 2016-17 to help high-impact (innovative) firms scale up and further their global competitiveness, increasing small business dynamism. Under this client-centred approach, firms will be able to access coordinated services (such as finance, advice and export and innovation support) from the relevant federal agencies tailored to their needs. This initiative aims to target 1000 firms in the first few years and to expand thereafter.

\begin{tabular}{|l}
\hline $\begin{array}{l}\text { Recommendations to enhance the contribution to productivity of small business financing } \\
\text { programmes }\end{array}$ \\
- $\begin{array}{l}\text { Review small business support to identify clear capital-market failures and the policy instruments best } \\
\text { suited to addressing them. }\end{array}$ \\
- $\begin{array}{l}\text { Review Business Development Bank of Canada programmes to ensure that they are focussed on } \\
\text { efficiently addressing clear capital-market failures. }\end{array}$ \\
- Encourage the Business Development Bank of Canada venture capital arm to shift from direct seed \\
capital investments to passive side-car investments with angel investors. \\
Phase out remaining federal tax credits for provincial Labour-Sponsored Venture Capital Corporations \\
and explore whether to make greater use of funds that operate like private, independent, limited \\
partnership venture capital funds, as was the case with the Venture Capital Action Plan.
\end{tabular}

\section{Enhanced $R \& D$ tax credits for small companies}

Canadian governments provide higher tax credits to small CCPCs with qualifying annual R\&D expenditures up to CAD 3 million than to other companies. At the federal level, the enhanced Scientific Research and Experimental Development (SR\&ED) refundable tax credit is 35\%. The "expenditure limit" for the enhanced credits is reduced to zero as taxable income rises from CAD 500000 to CAD 800000 and as taxable capital rises from CAD 10 million to CAD 50 million. The enhanced credits are fully refundable. R\&D spending in excess of the expenditure limit is eligible for the standard $15 \%$ tax credit. For firms with taxable income of CAD 500000 or less or taxable capital of CAD 10 million or less, $40 \%$ of credits earned at the general rate are also refundable. Provincial governments also provide SR\&ED tax credits, bringing the weighted average of federal-provincial enhanced and standard rates to $43 \%$ and $20 \%$, respectively.

The implied SME tax subsidy rates in Canada are very high by international comparison (Figure 15). Abstracting from provincial subsidies, the SME subsidy rate per marginal unit of R\&D outlay (as measured by one minus the B-index) is $30 \%$, which is in the top quartile of rates across OECD countries. The enhancement over the $13 \%$ large profitable company rate is one of the greatest among OECD countries. Combined with provincial tax support, the SME R\&D tax subsidy rate can reach $40 \%$, as in Quebec, which provides one of the most generous fully refundable R\&D tax credits among Canadian provinces. 

2016a):

Governments subsidise business R\&D to correct for two major types of market failures (OECD,

- Externalities. Firms have difficulty fully appropriating the returns on their investments, as some of the resulting knowledge spills over to other firms, leading firms to underinvest in innovation relative to the socially optimal level.

- Asymmetric information in capital markets. Firms have difficulty finding external finance for innovation, especially if they are small or young. Innovation is a highly uncertain activity with large differences in the information available to inventors and investors, respectively. This may imply that external capital for innovation will be available at too high a cost or may not be available at all.

Figure 15. Implied tax subsidy rates ${ }^{1}$ on $R \& D$ expenditures

1-B-Index, ${ }^{2}$ by firm size and profit scenario, 2015

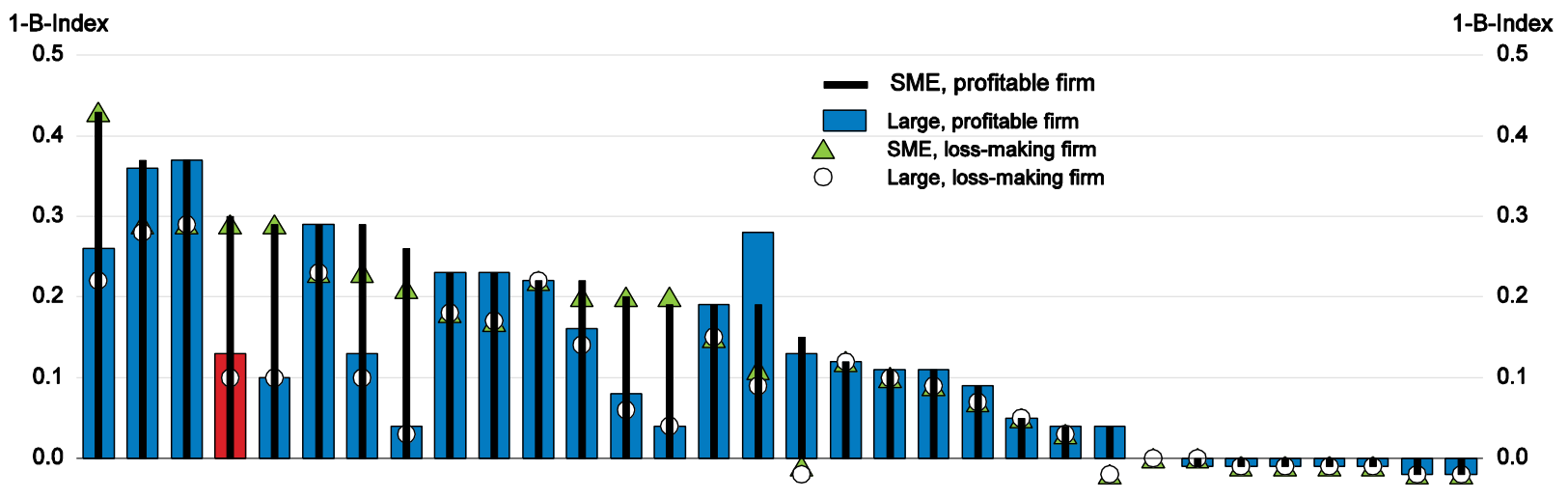

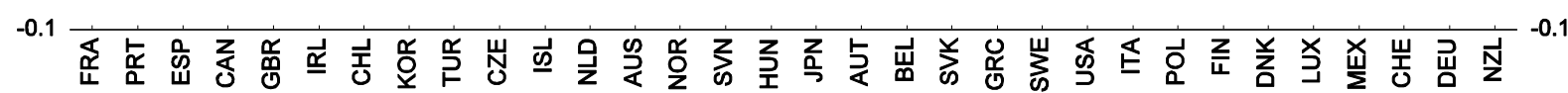

1. These implied tax subsidy rates focus only on central government support and do not report provincial tax incentives.

2. The B-index, a measure of the pre-tax income needed for a company to break even on a marginal, monetary unit of R\&D outlay (OECD, 2013), takes into account tax relief provisions to derive implied tax subsidy rates (1 minus the B-index).

Source: OECD (2016), "R\&D tax Incentives; Design and Evidence", DSTI/IND/STP(2016)1, Figure 1; OECD (2013), "Definition, Interpretation and Calculation of the B index", Measuring R\&D Tax Incentives, October. http://www.oecd.org/sti/b-index.pdf.

Insofar as this is the rationale for public support for $\mathrm{R} \& \mathrm{D}$, it is impossible to judge a priori the implications for the SME subsidy rate relative to the standard rate. Asymmetric information in capital markets implies that small firms may be more credit constrained, pointing to a higher optimal SME subsidy rate, especially for young SMEs as they tend to be more innovative than old SMEs (Haltiwanger et al., 2013; Criscuolo et al., 2014); tighter credit constraints on small firms may lie behind their apparent greater responsiveness to R\&D tax incentives than larger firms (Baghana and Mohnen, 2009; OECD, 2016a). On the other hand, Bloom et al. (2013) suggest that smaller firms generate lower social returns to R\&D because they operate more in technological niches, pointing to lower optimal SME subsidy rates. Canada's high increment in R\&D subsidies for SMEs relative to other firms by international comparison raises questions about whether this is the right balance. To resolve this and other R\&D subsidy issues, such as the appropriate balance between direct and indirect support (Canada relies heavily on indirect support) and the level of the standard tax credit rate, the authorities should evaluate R\&D subsidy policies to ensure that they are providing value for money, as recommended by the OECD (2016a). 


\section{Recommendation to achieve greater value for money from R\&D subsidies}

- $\quad$ Evaluate R\&D subsidy policies to determine whether their structure, including a substantially enhanced R\&D tax credit rate for small companies and a heavy reliance on indirect measures, and the level of the standard $R \& D$ tax credit rate are providing value for money.

\section{Non-targeted tax measures supporting entrepreneurship}

The federal government also supports entrepreneurship through other tax measures. Three of the four measures - the lifetime capital gains exemption (LCGE), the deduction of allowable business investment losses (ABIL) and the rollover of investment in small business shares - reduce the capital gains tax on entrepreneurial activity. None of them is targeted at high-impact entrepreneurs, but they are of particular benefit to investors and entrepreneurs undertaking high-risk projects where the return is realised largely through capital gains. The fourth provides more favourable tax treatment of labour income in the form of stock options.

\section{The lifetime capital gains tax exemption is an inefficient way to support entrepreneurial activity}

The lifetime capital gains tax exemption (LCGE) exempts up to CAD 813600 (2015 value, indexed to inflation) in capital gains on the sale of qualifying shares in CCPCs from taxation over a taxpayer's lifetime, provided that certain conditions are met. CCPC shareholders may choose to realise a capital gain if the firm goes public. The objectives of the LCGE are to "bolster risk taking and investment in small businesses, help small business owners to accumulate funds for retirement and facilitate intergenerational transfers" (Finance Canada, 2010, p. 42). The amount of tax revenue forgone in 2014 was CAD 580 million (see Table 2).

A case can be made for providing preferential capital gains tax treatment for entrepreneurs starting a high-risk, potentially high-growth business and for outside equity investors, both of whom take returns largely in the form of capital gains. As noted above, such firms contribute disproportionately to innovation, both by closing the gap between global and national productivity frontier firms and by helping to diffuse technical progress. These effects entail spill-over benefits that are not rewarded in the market. Moreover, as discussed in Box 2, both entrepreneurs and venture capitalists invest less energy in the business than would be optimal, because neither receives the full reward for their effort.

While the LCGE should attenuate these market failures, it has a number of drawbacks:

- Marginal benefits for venture capitalists fall to zero quickly, because they would rapidly exhaust their lifetime limit.

- It distorts the choice of organisational form away from sole proprietorships, partnerships and public companies towards CCPCs, the only organisational form that qualifies.

- By facilitating intergenerational transmission of businesses, it reduces productivity as firms inherited by family members tend to underperform those with management selected based on other criteria (Andrews et al., 2015).

If it is felt that there is a compelling economic case for at least partially exempting capital gains taxation on investing in high-growth companies, it may be preferable to replace the LCGE by a measure along the lines of that in the United States, which provides a 100\% reduction in capital gains tax for shares issued by small businesses (with less than USD 50 million in assets) when they become public companies (PATH Act). This benefits both entrepreneurs and venture capital investors fully. 


\section{Recommendation to re-orient capital gains taxation to provide greater support to innovative entrepreneurs}

- Replace the lifetime capital gains tax exemption by a more targeted measure of benefit to high-potential young firms.

The deduction for allowable business investment losses could be improved

In most circumstances, capital losses can be deducted only from realised capital gains. This policy prevents taxpayers from deducting capital losses as they occur while deferring taxes on unrealised capital gains. While justifiable as a measure to protect the tax base, the asymmetric treatment of capital gains and losses may be particularly burdensome for owners of young firms, who may be more likely to have capital losses without offsetting capital gains.

For small businesses, the deduction for allowable business investment losses (ABIL) gets around the problem of asymmetric treatment by allowing half of losses (corresponding to the half inclusion rate of capital gains) incurred on shares or debt issued to be deducted from ordinary income. If the ABIL exceeds other sources of income for the year, the excess may be converted to a non-capital loss that may be carried back three years or forward ten years, after which it becomes a net capital loss that can be deducted only from realised capital gains. As taxpayers making use of an ABIL are not first required to deduct the loss against unrealised capital gains, claimants continue to benefit from a tax deferral.

The amount of personal income tax revenue foregone in 2013 as a result of ABILs was CAD 35 million (see Table 2). This is surprisingly small, given that almost half of all firms fail in the first three years after start-up (Macdonald, 2012). Part of the explanation is the requirement that losses be first applied against capital gains deductions (the LCGE multiplied by the capital gains inclusion rate) claimed in earlier years. Another reason is that the cost of converting an ABIL to a non-capital loss is not included in the tax expenditure estimate.

There are a number of adjustments to the ABIL that could be made to focus it more on start-ups, which may have more beneficial effects on productivity than other small firms. First, the carry-forward of ABILs converted to non-capital losses could be increased over time to maintain a constant present value. Second, although ABILs can be transferred to a spouse or partner by transferring the underlying asset, a simpler, direct transfer of the deduction could be allowed. Third, capital losses on unincorporated business ventures could be made eligible for the deduction to avoid biasing the choice of business form.

\section{Increasing women's entrepreneurship}

Female entrepreneurship rates are lower than male rates on a variety of measures. In 2011, only $15.5 \%$ of SMEs were majority-female owned, compared with $66.4 \%$ that were majority owned by males; the other $18.1 \%$ of SMEs were owned equally by the two (Industry Canada, 2015). Majority female-owned SMEs tend to be slightly smaller on average than their majority male-owned counterparts - 59\% only had one to four employees, compared with $51 \%$ for majority male-owned SMEs. Moreover, majority female-owned SMEs' actual and expected growth rates were lower than for majority male-owned SMEs (Table 5). Selfemployed women are much more likely to work part-time than self-employed men and female employees (Figure 16). Female entrepreneurs also tend to set a lower maximum size for their businesses beyond which they are not interested in growing than their male counterparts (Cliff, 1998). One such growthlimiting strategy is not to export. Indeed, a firm's propensity to export and ability to penetrate international markets are good indicators of growth aspirations and potential (Institute for Competitiveness and Prosperity, 2012). In 2011, only 5\% of majority female-owned SMEs exported, compared with $12 \%$ for majority male-owned SMEs (Industry Canada, 2015). Even after controlling for sector, firm and owner 
attributes, male-owned SMEs have a higher tendency to export (Orser et al., 2010). Narrowing these entrepreneurship gaps would increase productivity growth and social inclusion (not least because women are over-represented in social entrepreneurship and innovation that seeks to address community and social needs).

Table 5. Distribution of SME ownership

\begin{tabular}{|c|c|c|c|}
\hline \multicolumn{4}{|c|}{ A. By reported annual revenue growth rates, 2011-14 } \\
\hline Growth Rate & Majority Female-Owned & Majority Male-Owned & Equal Ownership \\
\hline $\begin{array}{l}<0 \% \text { (negative } \\
\text { sales growth) }\end{array}$ & 11.9 & 11.7 & 10.3 \\
\hline $0 \%$ (no growth) & 19.5 & 18.8 & 16.9 \\
\hline $1-10 \%$ per year & 51.9 & 48.0 & 53.6 \\
\hline $11-20 \%$ per year & 10.3 & 11.5 & 10.4 \\
\hline$>20 \%$ per year & 6.4 & 10.0 & 8.8 \\
\hline \multicolumn{4}{|c|}{ B. By expectations for growth, 2015-17 } \\
\hline Growth Rate & Majority Female-Owned & Majority Male-Owned & Equal Ownership \\
\hline$<0 \%$ (decline) & 5.3 & 5.9 & 6.7 \\
\hline $0 \%$ (no growth) & 18.8 & 16.7 & 15.8 \\
\hline $1-10 \%$ per year & 51.9 & 56.1 & 59.0 \\
\hline $11-20 \%$ per year & 16.3 & 12.8 & 12.7 \\
\hline$>20 \%$ per year & 7.6 & 8.6 & 5.8 \\
\hline
\end{tabular}

Note: Percentage may not add to 100 due to rounding.

Source: Statistics Canada, Survey on Financing and Growth of Small and Medium Enterprises, 2015.

Figure 16. Self-employment differences by gender, 2015
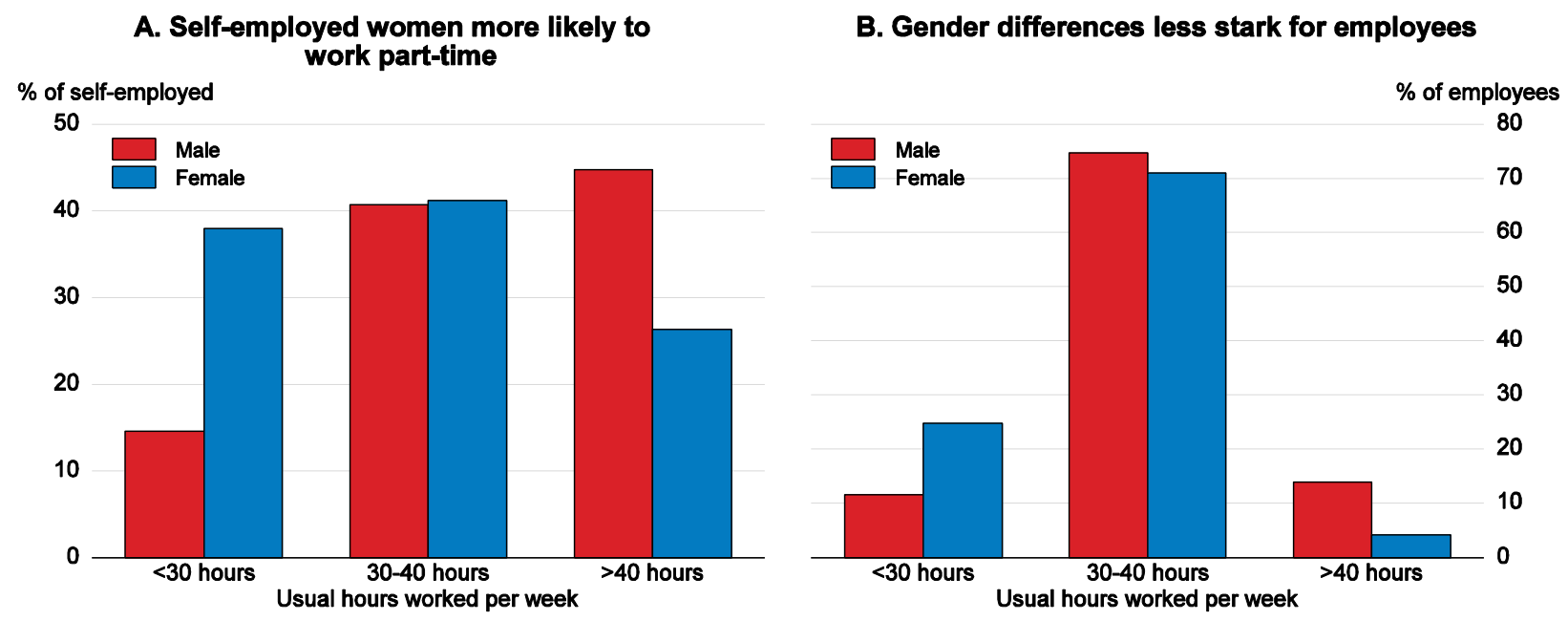

Source: Statistics Canada, Table 284-0024.

Factors contributing to these gender gaps include female entrepreneurs having less management experience, less access to finance, greater childcare and eldercare responsibilities and less effective networks for accessing resources, and being more concentrated in service sectors that are characterised by ease of entry and intense competition than men (OECD, 2016b; Hughes, 2006): 
- In 2011, 68\% of majority female-owned SMEs' owners had over 10 years' experience in 2011, compared with 79\% for their male counterparts (Industry Canada, 2015).

- In 2011,67\% of majority female-owned SMEs had loan requests rejected because of insufficient collateral and $66 \%$ because of operating in an unstable industry as against only $36 \%$ and $25 \%$, respectively for their male counterparts (Industry Canada, 2015).

- In 2011, 21\% of majority female-owned SMEs are in retailing compared with $12 \%$ of majority male-owned firms, while there are far fewer women than men in high-technology manufacturing and knowledge-intensive service sectors, where growth opportunities tend to be stronger (Industry Canada, 2015).

- A smaller proportion of women than men (53\% of women, $71 \%$ of men) are motivated by classic pull factors, such as independence, desire to be one's own boss, and earn more money, while a larger proportion of women are motivated by achieving a better work-family balance $(25 \%$ of women, $7 \%$ of men) (Hughes, 2006). These factors contribute to the gender gaps in actual and expected growth and in the propensity to export noted above.

To address some of these issues, recent budgets included measures to foster networking, encourage mentoring and championing, enhance access to international markets and provide finance (through the Business Development Bank of Canada). These measures could be built on by scaling up business development support to growth-oriented female-owned ventures. The highly successful 'Grow to Greatness' accelerator programme of Alberta Women Entrepreneurs provides a role model for other provinces and territories.

To facilitate female entry into high-technology manufacturing and knowledge-intensive service sectors, where growth opportunities tend to be stronger, women should be given greater encouragement to obtain STEM (science, technology, engineering and mathematics) qualifications and pursue related careers, while stereotypes associating males with greater success in these fields should continue to be confronted. Overwhelmingly, founders of leading global tech companies and of the top 250 Canadian tech companies have university degrees in science and engineering (Institute for Competitiveness and Prosperity, 2012). As in many other countries, women are under-represented in these fields in Canada: in 2011 , only $39 \%$ of people aged 25-34 with a university degree in a STEM field were women, compared to $59 \%$ in all fields (Hango, 2013).

Federal entrepreneurship programmes would also be more effective in increasing female entrepreneurship if they were extended to social enterprises, which tend to attract female entrepreneurs more than their male counterparts. Increasing assistance with child-care costs, which are relatively high in Canada by international comparison (OECD, 2014), could help female entrepreneurs constrained by family responsibilities to pursue more growth-oriented strategies, as do their male equivalents.

\section{Recommendation to support female entrepreneurship}

- Scale up business development support to growth-oriented female ventures.

\section{Increasing entrepreneurship of Indigenous Peoples}

Indigenous Peoples are also under-represented in SME ownership - 2\% of SMEs are operated by Indigenous entrepreneurs, about half of their share in the total population (Gulati, 2012). There are 
organisations dedicated to strengthening networks of entrepreneurs, mentoring and entrepreneurial skills, helping to develop successful role models in the process, but these efforts need to be reinforced. To promote Indigenous entrepreneurship, the top priority is to invest in education and capacity building both in Economic Development Corporations (how to set up and run one and create effective corporate governance arrangements), which are community firms that account for most Indigenous SME income, and for the community at large (job and skills training) (Gulati and Burleton, 2015). Indigenous firms also need better access to IT infrastructure $-20 \%$ of those in Ontario did not have an Internet connection in 2013, rising to $37 \%$ for those on reserves (Canadian Council for Aboriginal Business, 2014). 


\section{BIBLIOGRAPHY}

Andrews, D. and F. Cingano (2014), "Public Policy and Resource Allocation: Evidence from Firms in OECD Countries", Economic Policy, Vol. 29, No. 78, pp 253-96.

Andrews, D., C. Criscuolo and P. Gal (2015), "Frontier Firms, Technology Diffusion and Public Policy: Micro Evidence from OECD Countries", in The Future of Productivity: Main Background Papers, OECD Publishing, Paris.

Andrews, D., C. Criscuolo, C. Menon (2014), "Do Resources Flow to Patenting Firms? Cross-Country Evidence from Firm Level Data", OECD Economics Department Working Papers, No. 1127, OECD Publishing, Paris.

Baghana, R. and P. Mohnen (2009), 'Effectiveness of R\&D Tax Incentives in Small and Large Enterprises in Québec'. Small Business Economics, Vol. 33, No. 1, pp. 91-107 doi:10.1007/s11187-009-9180-z.

Balakrishnan, R. (2008), “Canadian Firm and Job Dynamics”, IMF Working Paper, WP/08/31.

Baldwin, J. and W. Gu (2006), "Competition, Firm Turnover and Productivity Growth", Statistics Canada Research Paper, 11F0027MIE No. 42.

Baldwin, J., D. Leung and L. Rispoli (2014), "Canada-United States Labour Productivity Gap Across Firm Size Classes”, Research Paper, The Canadian Productivity Review, Statistics Canada.

Baumol, W. (2002), The Free-Market Innovation Machine: Analyzing the Growth Miracle of Capitalism, Princeton University Press.

Bazel, P. and J. Mintz (2016), forthcoming paper, cited in J. Mintz (2015), "An Agenda for Corporate Tax Reform in Canada", Canadian Council of Chief Executives, September.

Bloom, N., M. Schankerman and J. Van Reenen (2013), "Identifying Technology Spillovers and Product Market Rivalry", Econometrica, Vol. 81, Issue 4, pp. 1347-93, July.

Boadway, R. and M. Keen (2006), "Financing and Taxing New Firms under Asymmetric Information", FinanzArchiv/Public Finance Analysis vol. 62, no. 4 pp. 471 - 502.

Boadway, R. and M. Sato (1999), "Information Acquisition and Government Intervention in Credit Markets” Journal of Public Economic Theory, Vol. 1, No. 3, pp. 283-308.

Braido, L., C. da Costa and B. Dahlby (2011), "Adverse Selection and Risk Aversion in Capital Markets" FinanzArchiv / Public Finance Analysis, Vol. 67, No. 4, pp. 1-24.

Brander, J., E. Egan and T. Hellmann (2008), “Government Sponsored versus Private Venture Capital: Canadian Evidence”, NBER Working Papers, No. 14029, May.

Brander, J., T. Hellmann and T. Meredith (2012), "What Ottawa Can Do", in Policy Options, Institute for Research on Public Policy, Montréal, Vol. 33, No. 10, November, pp. 42-44.

Business Development Bank of Canada (BDC) (2004), Annual Report. 
BDC (2011), Venture Capital Industry Review, February.

BDC (2015), BDC Corporate Plan Summary, 2015-16 to 2019-20.

Calvino, F., C. Criscuolo and C. Menon (2015), "Cross-country evidence on start-up dynamics", OECD Science, Technology and Industry Policy Papers, No. 6, OECD Publishing, Paris.

Calvino, F., C. Criscuolo and C. Menon (2016), "No Country for Young Firms?: Start-up Dynamics and National Policies", OECD Science, Technology and Industry Policy Papers, No. 29, OECD Publishing, Paris.

Canadian Council for Aboriginal Business (2015), "Community and Commerce: A Survey of Aboriginal Economic Development Corporations in Ontario", Research Report, Spring.

Cao, S. and D. Leung (2010), "Labour Reallocation, Relative Prices and Productivity", Bank of Canada Working Paper, No. 2010-2.

Cao, S., M. Salameh, M. Seki and P. St-Amant (2015), "Trends in Firm Entry and New Entrepreneurship in Canada", Bank of Canada Discussion Paper, 2015-11, October.

Chen, D. and J. Mintz (2011), "Small Business Taxation: Revamping Incentives to Encourage Growth", University of Calgary School of Public Policy, SPP Papers, Vol. 4, Issue 7.

Cliff, J. (1998), "Does one size fit all? Exploring the relationship between attitudes towards growth, gender and business size", Journal of Business Venturing, Vol. 13, pp. 523-42.

Crawford, C. and J. Freedman (2010), "Small Business Taxation", in J. Mirrlees, S.Adam, T. Besley, R. Blundell, S. Bond, R. Chote, M. Gammie, P. Johnson, G. Myles and J. Poterba (eds), Dimensions of Tax Design: The Mirlees Review, Oxford: Oxford University Press for Institute for Fiscal Studies.

Criscuolo, C., P. Gal and C. Menon (2014), "The Dynamics of Employment Growth: New Evidence from 18 Countries”, OECD Science, Technology and Industry Policy Papers, No. 14, OECD Publishing.

Cumming, D. (2007a), "Financing Entrepreneurs: Better Canadian Policy for Venture Capital”, C.D. Howe Institute Commentary, No. 247, April.

Cumming, D. (2007b), "Government Policy towards Entrepreneurial Finance: Innovation Investment Funds", Journal of Business Venturing, Vol. 22, No. 2, pp. 193-235.

Cumming, D. and J. MacIntosh (2004), "Canadian Labour Sponsored Venture Capital Corporations: Bane or Boon?" in A. Ginsberg and I. Hasan (eds.), New Venture Investment: Choices and Consequences, Elsevier Academic Press, Amsterdam and Boston.

Cumming, D. and J. MacIntosh (2006), "Crowding Out Private Equity: Canadian Evidence", Journal of Business Venturing, Vol. 21, No. 5, pp. 569-609.

Cumming, D. and J. MacIntosh (2007), "Mutual Funds that Invest in Private Equity? An Analysis of Labour Sponsored Investment Funds", Cambridge Journal of Economics, Vol. 31, pp. 445-87.

Dietz, M. (2002), "Risk, Self-Selection, and Advice: Banks versus Venture Capitalists”, University of St. Gallen, Institute of Public Finance and Fiscal Law http://papers.ssrn.com/sol3/papers.cfm?abstract id=302080). 
Elitzura, R. and A. Gavious (2003), "Contracting, signaling, and moral hazard: a model of entrepreneurs, 'angels,' and venture capitalists", Journal of Business Venturing, Vol. 18, pp. 709-25.

Finance Canada (2010), Tax Expenditures: Notes to the Estimates/Projections http://www.fin.gc.ca/taxexpdepfisc/2010/taxexp1004-eng.asp

Finance Canada (2013), Tax Expenditures and Evaluation 2012: Part 2 - Taxation of Small Businesses in Canada.

Freedman, J. (2009), "Reforming the Business Tax System: Does Size Matter? Fundamental Issues in Small Business Taxation", in C. Evans and R. Kever (2009), Australian Business Tax Reform in Retrospect and Prospect, pp. 153-78.

Government of Canada (1995), Business Development Bank of Canada Act http://loislaws.justice.gc.ca/eng/acts/B-9.9/FullText.html

Graham, T. (2004), Graham Review of the Small Firms Loan Guarantee: Recommendations, HMSO.

Gulati, S. (2012), "Canada's Small and Medium-Sized Business Owners: Diverse Society in a Microcosm", TD Economics Special Report, 12 October.

Gulati, S. and D. Burleton (2015), "The Long and Winding Road Towards Aboriginal Economic Prosperity", TD Economics Special Report, 10 June.

Haltiwanger, J. (2012), “Job Creation and Firm Dynamics in the United States”, in Innovation Policy and the Economy, edited by J. Lerner and S. Stern, pp. 17-38, NBER/Chicago Press.

Haltiwanger, J., R. Jarmin and J. Miranda (2013), 'Who Creates Jobs? Small versus Large versus Young' Review of Economics and Statistics, Vol. 95, No. 2, pp. 347-61. doi:10.1162/REST_a_00288.

Haltiwanger, J., S. Scarpetta and H. Schweiger (2006), "Assessing Job Flows Across Countries: The Role of Industry, Firm Size, and Regulations", World Bank Policy Research Working Paper, No. 4070.

Hango, D. (2013), "Gender differences in science, technology, engineering, mathematics and computer science (STEM) programs at university", Statistics Canada Insights on Canadian Society, Catalogue no. $75-006-X$.

Henderson, R. (1993), "Underinvestment and Incompetence as Responses to Radical Innovation: Evidence from the Photolithographic Alignment Equipment Industry", RAND Journal of Economics, Vol. 24, No. 2, pp. 248-70.

Hughes, K. (2006), "Exploring Motivation and Success Among Canadian Women Entrepreneurs", Journal of Small Business and Entrepreneurship, Vol. 19, No. 2.

Industry Canada (2007), Venture Capital Monitor, Q4.

Industry Canada (2013), "SME Regulatory Compliance Cost Report", Report of the Paperwork Burden Reduction Initiative, September, Ottawa.

Industry Canada (2014a), Canada Small Business Financing Act-Annual Report 2013-14. https://www.ic.gc.ca/eic/site/csbfp-pfpec.nsf/eng/h la03257.html 
Industry Canada (2014b), Evaluation of the Canada Small Business Financing Program (http://www.ic.gc.ca/eic/site/ae-ve.nsf/eng/03715.html?Open\&pv=1)

Industry Canada (2014c), Venture Capital Monitor, Q4.

Industry Canada (2015), Majority Female-Owned Small and Medium-Sized Enterprises, Special Edition: Key Small Business Statistics, May.

Institute for Competitiveness and Prosperity (2012), "Small Business, Entrepreneurship, and Innovation", Working Paper, No. 15, February.

Jenkins, G. and G. Kuo (2007), “The Economic Opportunity Cost of Capital for Canada -- An Empirical Update”, Queen's Economics Department Working Paper, No. 1133.

Lerner, J. (1999), "The Government as Venture Capitalist: The Long-Run Impact of the SBIR Program", Journal of Business, Vol. 72, No. 3, pp. 285-318.

Lerner, J. (2010), "The Future of Public Efforts to Boost Entrepreneurship and Venture Capital”, Small Business Economics, Vol. 35, Issue 3, pp. 255-64.

Lester, J. (2016), "Policy Interventions Favouring Small Business: Rationales, Results and Recommendations", forthcoming.

Macdonald, R. (2012), "Firm Dynamics: The Death of New Canadian Firms: A Survival Analysis of the 2002 Cohort of Entrants to the Business Sector", Statistics Canada Research Paper in the Canadian Economy in Transition Series, Catalogue No. 11-622-M - No. 028.

R. A. Malatest and Associates Ltd. (2014), CSBFP Lender Awareness and Satisfaction Study, Prepared for Industry Canada https://www.ic.gc.ca/eic/site/csbfp-pfpec.nsf/eng/la03244.html

Mirrlees, J., S.Adam, T. Besley, R. Blundell, S. Bond, R. Chote, M. Gammie, P. Johnson, G. Myles and J. Poterba (eds.) (2010), Dimensions of Tax Design: The Mirrlees Review, Oxford: Oxford University Press for the Institute for Fiscal Studies.

OECD (2013), "Definition, interpretation and calculation of the B index", Measuring R\&D tax incentives, October 2013. http://www.oecd.org/sti/b-index.pdf

OECD (2014), OECD Tax-benefit model 2014, OECD Publishing, Paris.

OECD (2015a), "The Future of Productivity: Firm Dynamics and Productivity Growth in Europe", ECO/CPE/WP1(2015)6/ANN3.

OECD (2015c), "Taxation of SMEs in OECD and G20 Countries", OECD Tax Policy Studies, No. 23, OECD Publishing, Paris.

OECD (2016a), R\&D Tax Incentives: Design and Evidence, DSTI/IND/STP(2016)1.

OECD (2016b) (forthcoming), Review of SME and Entrepreneurship Policies and Programmes in Canada, Paris. (First draft report - CFE/SME(2015)9).

OECD (2016c), OECD Economic Surveys: Canada 2016, OECD Publishing, Paris. http://dx.doi.org/10.1787/eco_surveys-can-2016-en 
Orser, B., M. Spence, A. Riding and C. Carrington (2010), "Gender and Export Propensity", Entrepreneurship Theory and Practice, Vol. 34, pp. 933-57.

Seens, D. and M. Song (2015), Requantifying the Rate of Incrementality for the Canada Small Business Financing Program, Industry Canada, Small Business Branch, March. (http://www.ic.gc.ca/eic/site/061.nsf/eng/02939.html?Open\&pv=1)

Wolfson, M., M. Veall and N. Brooks (2014), "Piercing the Veil - Private Corporations and the Income of the Affluent", https://uwaterloo.ca/school-of-accounting-and-finance/sites/ca.school-of-accountingand-finance/files/uploads/files/wolfson-brooks-veall_-_incomes_of_affluent.pdf 